\title{
New Indomalayan Nebularmis species (Heterotardigrada: Echiniscidae) provoke a discussion on its intrageneric diversity
}

\author{
Piotr Gąsiorek ${ }^{1 *} \mathbb{D}$, Katarzyna Vončina ${ }^{1}$, Joanna Ciosek', Mariana Veloso ${ }^{2}$, Paulo Fontoura ${ }^{2,3}$ and Łukasz Michalczyk ${ }^{1}$
}

\begin{abstract}
Recent years have brought undeniable progress in tardigrade taxonomy, and speciose complexes were detected in a number of phylogenetic lineages. The family Echiniscidae is one such lineage; it is one of the most diverse groups of limno-terrestrial tardigrades and can be characterized as having achieved great evolutionary success. In this contribution, using populations representing several species that originated from the Indomalayan region, we reconstructed phylogenetic affinities within Nebularmis, a recently erected genus within the Echiniscus lineage. Nebularmis auratus sp. nov. and Nebularmis burmensis sp. nov. are described from the Eastern Yoma Mountains and the Shan Hills (Myanmar), Nebularmis bhutanensis sp. nov. is described from the Eastern Himalayas (Bhutan), and Nebularmis indicus sp. nov. is described from the foothills of the Western Ghats (Goa, India). Moreover, males are reported in populations of the last two species. All known members of the genus can be phenotypically differentiated based on minute details of their dorsal sculpture and claws. Moreover, a very wide tropical distribution is demonstrated for Nebularmis cirinoi, recorded for the first time from islands of the Malay Archipelago. Furthemore, novel morphological, genetic, and geographic data allowed for the clarification of the generic diagnosis. Currently available data favor a scenario under which Nebularmis evolved in Southeast Asia and later dispersed to other regions of the globe.
\end{abstract}

Keywords: Cuticle, Morphology, Oriental region, Phylogeny, Pseudocryptic species, Taxonomy

\section{Background}

The diversity of tardigrades has been intensively studied in recent years using modern species delimitation tools, including statistical morphometry and molecular analyses. Consequently, numerous new species have been detected in every major lineage of the phylum, and many are currently awaiting formal descriptions. Among marine heterotardigrades, examples include Echiniscoides and Batillipes [1, 2], terrestrial heterotardigrade examples (predominantly echiniscids) are present in

\footnotetext{
* Correspondence: piotr.lukas.gasiorek@gmail.com

'Department of Invertebrate Evolution, Institute of Zoology and Biomedical Research, Faculty of Biology, Jagiellonian University, Gronostajowa 9, 30-387 Kraków, Poland

Full list of author information is available at the end of the article
}

Pseudechiniscus and Hypechiniscus [3, 4], in the eutardigrade order Apochela, the genus Milnesium was recently demonstrated to be rich in species [5], and examples of hyperdiversity are highly elaborate in the other eutardigrade order, Parachela, which contains such intensively studied genera as Macrobiotus, Ramazzottius, Richtersius, Paramacrobiotus and Platicrista [6-11]. Resolving many taxonomic uncertainties not only enhanced overall tardigrade classification [12] by narrowing the extent of intraspecific variability, which was traditionally considered sizeable [13, 14], but also contributed, for example, to the recognition of Hypsibius exemplaris as a new model metazoan species [15] that is crucial in research on animal development and cryptobiosis (e.g., $[16,17])$. As a consequence of the collaborative endeavors of 
tardigradologists, tens of new species are described every year [18-22].

Comprising more than a hundred species, Echiniscus competes with Macrobiotus for the position of the most speciose tardigrade genus [23]. High taxonomic importance was typically assigned to dorsal sculpturing in the Echiniscus lineage [24]; recently, following the recognition that the phylogenetic position appeared congruent with morphological data, new monophyletic genera were separated from Echiniscus [25, 26]. One of these genera, Nebularmis, was created for the widespread Palearctic species Nebularmis reticulatus [27, 28] and its kin. These echiniscids exhibit unique dorsal sculpturing that consists of a sponge-like intracuticular layer and large, circular or slightly hexagonal, flat epicuticular granules that may merge, giving the plates an unsculptured appearance, a morphological state unknown in the remainder of the family. Moreover, Nebularmis has large red eyes and a highly altered ventral cuticular system, with uniform wrinkling in the central part of the venter and characteristic, clearly delineated, thick and densely granulated subcephalic and genital plates. Such a combination of traits makes Nebularmis easy to recognize; nevertheless, the state of taxonomy within the genus leaves much to be desired. Almost all known Nebularmis species are dubious, most likely synonymous with $N$. reticulatus [28], and some other potentially valid species, such as the Neotropical Nebularmis phocae [29], cannot be identified without redescriptions, as their descriptions are too general. Poor species descriptions continue to be a serious problem when linking the traditionally morphologically based Linnean system of classification with the proliferating use of integrative taxonomic methods [30], posing difficulties that threaten the stability and reliability of tardigrade systematics [31].

With the opportunity to analyse many Indomalayan populations representing this uncommon genus, we aim to present the intrageneric diversity and phylogeography of Nebularmis in a new light. Four new species are described from regions that were not previously subjected to tardigrade sampling [32], illustrating that Southeast Asia may be an important source of diversity in this phylum and attain similar status to other established biodiversity hotspots [33]. We amend the definition of Nebularmis based on new morphological data, present hypotheses on its evolution, and finally discuss our findings in the context of phylogeny of echiniscids, one of the stunningly morphologically complex tardigrade groups [34]. Last, we appeal for doubling the effort in creating a list of available names in Tardigrada ahead of the forthcoming $15^{\text {th }}$ International Symposium on Tardigrada, as has been successfully undertaken for another meiofaunal phylum, Rotifera [35], to officially abandon the names of tens of unidentifiable species.

\section{Materials and methods \\ Sampling, data collection, comparative material and terminology}

Individuals belonging to the rare genus Nebularmis were extracted from 11 moss and lichen samples collected in South and Southeast Asia (details in Table 1). Samples were air-dried, sealed in paper envelopes, subsequently rehydrated using tap water, and vigorously shaken in beakers; then, the supernatant was transferred to measuring cylinders. After removal of excess water, sediments containing bryophilous and lichenophilous animals and plant particles were poured onto Petri dishes, and tardigrades were detected using stereomicroscopes. Each specimen was drawn into a glass pipette and placed in distilled water. After extraction, the animals were divided into three groups to be used in different analyses: (I) qualitative and quantitative morphological investigations with light contrast microscopy (LCM), specifically phase contrast (PCM) and Nomarski differential interference contrast microscopy (NCM); (II) qualitative morphological observation with scanning electron microscopy (SEM); and (III) DNA sequencing analysis. Specimens of Nebularmis spp. inhabiting the Ruwenzori Mountains ( 1 individual; $2520 \mathrm{~m}$ asl, granite stones at the edge of a stream; vicinity of Mubuku, Uganda, Africa; leg. J. Michejda, February 1974), Llanganuco Valley (1 individual; $2400 \mathrm{~m}$ asl, granite rocks; Cordillera Blanca, the Andes, Peru, South America; leg. L. Wilczyński, August 1973), Doi Inthanon (ZMUC-516, 519-20; 4 individuals; Thailand, Asia; leg. H. Enghoff, October 1981), and Greenland ([36], currently deposited in Copenhagen) were used for comparative purposes. Data from Gąsiorek et al. [28] were also utilized. Additionally, we examined specimens of Echiniscus palmai (NZ-381; 1 individual; ca. $560 \mathrm{~m}$ asl; the Haast Pass (Tioripatea), Mount Aspiring National Park, the South Island of New Zealand; leg. D.S. Horning, October 1970; NZ-525; 1 individual; Canaan Road, Abel Tasman National Park, the South Island of New Zealand; leg. D.S. Horning, April 1971).

The terminology for sclerotized structures follows that by Kristensen [34]. The division of a cephalic cirrus into cirrophore and flagellum is in accordance with Møbjerg et al. [37]. Isonych spurs share identical morphology on all claws, whereas heteronych spurs signify that the spurs on claw IV are different in size/shape/position on the claw branch than the spurs on claws I-III. Abbreviations used for scientific institutions are as follows: UJ - Jagiellonian 
Table 1 List of populations used in the analyses. Types of analyses: (LCM) imaging and morphometry using PCM/NCM, (SEM) imaging using SEM, (DNA) DNA sequencing. The number in each analysis indicates how many specimens were analyzed by a given method (a - adults, $v$ - exuvia, j - juveniles, I - larvae)

\begin{tabular}{|c|c|c|c|c|c|c|c|c|}
\hline \multirow[t]{2}{*}{ Species } & \multirow{2}{*}{$\begin{array}{l}\text { Sample } \\
\text { code }\end{array}$} & \multirow{2}{*}{$\begin{array}{l}\text { Coordinates } \\
\text { and altitude }\end{array}$} & \multirow[t]{2}{*}{ Locality } & \multirow[t]{2}{*}{ Sample type } & \multirow{2}{*}{$\begin{array}{l}\text { Collector and } \\
\text { collection date }\end{array}$} & \multicolumn{3}{|c|}{ Analyses } \\
\hline & & & & & & LCM & SEM & DNA \\
\hline $\begin{array}{l}\text { Nebularmis } \\
\text { auratus sp. nov. }\end{array}$ & MM.003 & $\begin{array}{l}17^{\circ} 28^{\prime} 55^{\prime \prime} \mathrm{N} \\
97^{\circ} 05^{\prime} 53^{\prime \prime} \mathrm{E} \\
1073 \mathrm{~m} \text { asl }\end{array}$ & $\begin{array}{l}\text { Myanmar, Mon, Eastern Yoma } \\
\text { Mountains, Kyaiktiyo }\end{array}$ & $\begin{array}{l}\text { moss from tree } \\
\text { bark }\end{array}$ & $\begin{array}{l}\text { Dominika Wilkosz; } \\
\text { 02.02.2016 }\end{array}$ & $\begin{array}{l}3 a+ \\
2 j\end{array}$ & - & $4 a$ \\
\hline $\begin{array}{l}\text { Nebularmis } \\
\text { bhutanensis sp. } \\
\text { nov. }\end{array}$ & BT.001 & $\begin{array}{l}37^{\circ} 29^{\prime} 32^{\prime \prime} \mathrm{N} \\
89^{\circ} 21^{\prime} 49^{\prime \prime} \mathrm{E} \\
3120 \mathrm{~m} \text { asl }\end{array}$ & $\begin{array}{l}\text { Bhutan, } \\
\text { Eastern Himalayas, Paro Taktsang }\end{array}$ & moss from rock & $\begin{array}{l}\text { Cristina Cruz \& Jorge } \\
\text { Domingos; } 28.08 .2018\end{array}$ & $3 a$ & - & - \\
\hline $\begin{array}{l}\text { Nebularmis } \\
\text { burmensis sp. } \\
\text { nov. }\end{array}$ & MM.010 & $\begin{array}{l}20^{\circ} 38^{\prime} 28^{\prime \prime} \mathrm{N} \\
97^{\circ} 04^{\prime} 14^{\prime \prime} \mathrm{E} \\
1333 \mathrm{~m} \text { asl }\end{array}$ & $\begin{array}{l}\text { Myanmar, Shan, Shan Hills, } \\
\text { Taunggyi, Kakku Pagodas }\end{array}$ & $\begin{array}{l}\text { moss and lichen } \\
\text { from tree bark }\end{array}$ & $\begin{array}{l}\text { Katarzyna Vončina; } \\
\text { 21.02.2019 }\end{array}$ & $\begin{array}{l}7 a+ \\
1 j+1 \\
1\end{array}$ & $3 a$ & $4 a$ \\
\hline \multirow[t]{4}{*}{ Nebularmis cirinoi } & ID.517 & $\begin{array}{l}1^{\circ} 51 ' 20^{\prime \prime} \mathrm{S} \\
120^{\circ} 19^{\prime \prime} 25^{\prime \prime} \mathrm{E} \\
1331 \mathrm{~m} \text { asl }\end{array}$ & $\begin{array}{l}\text { Indonesia, Celebes, Sulawesi } \\
\text { Tengah, Lore Lindu, Bada } \\
\text { Lembah }\end{array}$ & $\begin{array}{l}\text { moss from tree } \\
\text { bark }\end{array}$ & $\begin{array}{l}\text { Piotr Gąsiorek \& Artur } \\
\text { Oczkowski; } 25.08 .2017\end{array}$ & $\begin{array}{l}10 a+ \\
4 j\end{array}$ & $3 a$ & $2 a$ \\
\hline & ID.518 & $\begin{array}{l}1^{\circ} 511^{\prime} 20^{\prime \prime} \mathrm{S} \\
120^{\circ} 19^{\prime} 30^{\prime \prime} \mathrm{E} \\
1311 \mathrm{~m} \text { asl }\end{array}$ & $\begin{array}{l}\text { Indonesia, Celebes, Sulawesi } \\
\text { Tengah, Lore Lindu, Bada } \\
\text { Lembah }\end{array}$ & $\begin{array}{l}\text { moss and lichen } \\
\text { from tree bark }\end{array}$ & $\begin{array}{l}\text { Piotr Gąsiorek \& Artur } \\
\text { Oczkowski; } 25.08 .2017\end{array}$ & $2 a$ & - & - \\
\hline & ID.874 & $\begin{array}{l}0^{\circ} 39^{\prime} 55^{\prime \prime} \mathrm{N} \\
127^{\circ} 24^{\prime \prime} 38^{\prime \prime} \mathrm{E} \\
1211 \mathrm{~m} \text { asl }\end{array}$ & $\begin{array}{l}\text { Indonesia, Maluku Utara, Tidore, } \\
\text { Gunung Kiematubu }\end{array}$ & $\begin{array}{l}\text { moss and lichen } \\
\text { from tree bark }\end{array}$ & $\begin{array}{l}\text { Piotr Gąsiorek; } \\
\text { 04.07.2018 }\end{array}$ & $1 a$ & - & - \\
\hline & ID.882 & $\begin{array}{l}0^{\circ} 40^{\prime} 07^{\prime \prime} \mathrm{N} \\
127^{\circ} 24^{\prime} 53^{\prime \prime} \mathrm{E} \\
905 \mathrm{~m} \text { asl }\end{array}$ & $\begin{array}{l}\text { Indonesia, Maluku Utara, Tidore, } \\
\text { Gunung Kiematubu }\end{array}$ & $\begin{array}{l}\text { moss from tree } \\
\text { bark }\end{array}$ & $\begin{array}{l}\text { Piotr Gąsiorek; } \\
\text { 04.07.2018 }\end{array}$ & $1 a$ & - & - \\
\hline \multirow[t]{4}{*}{$\begin{array}{l}\text { Nebularmis } \\
\text { indicus sp. nov. }\end{array}$} & IN.040 & $\begin{array}{l}15^{\circ} 05^{\prime} 44^{\prime \prime} \mathrm{N} \\
74^{\circ} 12^{\prime} 411^{\prime \prime} \mathrm{E} \\
77 \mathrm{~m} \text { asl }\end{array}$ & $\begin{array}{l}\text { India, Goa, Western Ghats, } \\
\text { Netravali }\end{array}$ & $\begin{array}{l}\text { moss from tree } \\
\text { bark }\end{array}$ & $\begin{array}{l}\text { Joanna Ciosek; } \\
\text { 16.09.2019 }\end{array}$ & $3 a$ & - & $1 a$ \\
\hline & IN.041 & $\begin{array}{l}15^{\circ} 03^{\prime} 49^{\prime \prime} \mathrm{N} \\
74^{\circ} 14^{\prime} 17^{\prime \prime} \mathrm{E} \\
328 \mathrm{~m} \text { asl }\end{array}$ & $\begin{array}{l}\text { India, Goa, Western Ghats, } \\
\text { Netravali }\end{array}$ & $\begin{array}{l}\text { moss from } \\
\text { concrete wall }\end{array}$ & $\begin{array}{l}\text { Joanna Ciosek; } \\
\text { 16.09.2019 }\end{array}$ & $1 a$ & - & - \\
\hline & IN.075 & $\begin{array}{l}14^{\circ} 58^{\prime} 01^{\prime \prime} \mathrm{N} \\
74^{\circ} 09^{\prime} 30^{\prime \prime} \mathrm{E} \\
100 \mathrm{~m} \text { asl }\end{array}$ & $\begin{array}{l}\text { India, Goa, Western Ghats, } \\
\text { Cotigao }\end{array}$ & $\begin{array}{l}\text { moss from tree } \\
\text { bark in forest } \\
\text { canopy }\end{array}$ & $\begin{array}{l}\text { Joanna Ciosek; } \\
\text { 14.09.2019 }\end{array}$ & $1 \mathrm{j}$ & $2 a$ & $\begin{array}{l}1 \mathrm{v} \\
\text { with } \\
\text { eggs }\end{array}$ \\
\hline & IN.076 & $\begin{array}{l}14^{\circ} 58^{\prime} 01^{\prime \prime N} \\
74^{\circ} 09^{\prime} 30^{\prime \prime} \mathrm{E} \\
100 \mathrm{~m} \text { asl }\end{array}$ & $\begin{array}{l}\text { India, Goa, Western Ghats, } \\
\text { Cotigao }\end{array}$ & $\begin{array}{l}\text { moss from tree } \\
\text { bark in forest } \\
\text { canopy }\end{array}$ & $\begin{array}{l}\text { Joanna Ciosek; } \\
\text { 14.09.2019 }\end{array}$ & 11 & - & $1 a$ \\
\hline
\end{tabular}

University (Poland), UP - University of Porto (Portugal). The publication was registered in ZooBank under the following: urn:lsid:zoobank.org:pub: 162A7916-4D32-4BA3-9542-624D702BFD16.

\section{Microscopy, imaging and morphometry}

Specimens subjected to light microscopy and morphometry analyses were mounted in a small drop of Hoyer's medium and examined under an Olympus BX 51 PCM and NCM paired with an Olympus DP74 digital camera. Specimens for SEM imaging were $\mathrm{CO}_{2}$ critical pointdried, coated with gold and examined with a Versa 3D DualBeam SEM at the ATOMIN facility of Jagiellonian University. All figures were assembled in Corel PhotoPaint X8. For deep structures that could not be fully focused in a single LCM photograph, a series of images were taken at approximately every $0.1 \mathrm{~mm}$ of vertical focusing and then assembled manually in Corel PhotoPaint into a single deep-focus image. All measurements were performed using PCM. Structures were measured only when oriented properly and not broken or deformed. Body length was measured from the anterior to the posterior end of the body, excluding the hind legs. The $s p$ index is the ratio of the length of a given structure to the length of the scapular plate [38]. Morphometric data were handled using the Echiniscoidea ver. 1.3 template available from the Tardigrada Register, http://tardigrada.net/register [39]. Raw morphometric data for the new species were deposited in the Tardigrada Register under the following numbers: $0076(N$. auratus sp. nov.), 0077 (N. bhutanensis sp. nov.), 0078 ( N. burmensis sp. nov.), and 0079 ( $N$. indicus sp. nov.). DNA sequences were deposited in GenBank. 


\section{Genotyping and preliminary work on sequences}

DNA was extracted from individual animals following a Chelex $^{\circledast} 100$ resin (Bio-Rad) extraction method [40, 41]. Vouchers were obtained after extraction when possible [42]. Five DNA fragments were sequenced: the $18 \mathrm{~S}$ small ribosomal rRNA subunit, the $28 \mathrm{~S}$ large ribosomal rRNA subunit, internal transcribed spacers ITS-1 and ITS-2, and the cytochrome oxidase I (COI) subunit. All fragments were amplified and sequenced according to the protocols described in Stec et al. [41]; primers and original references for specific PCR programs are listed in Supplementary Material 1. GenBank accession numbers for all species are provided in Table 2. 18S rRNA, 28S rRNA, and ITS sequences were aligned with sequences from Echiniscus testudo [43] and Diploechiniscus oihonnae [44] as outgroups using the Q-INS-i strategy in MAFFT version $7[45,46]$. The aligned fragments were edited and checked manually in BioEdit [47], with gaps left intact. COI was aligned with the ClustalW Multiple Alignment tool [48] in BioEdit, and uncorrected pairwise distances were calculated using MEGA7 [49]. Alignments are provided in Supplementary Materials 2, 3, 4, 5 and 6 .

\section{Phylogenetic and biogeographic analyses}

The sequences for the nuclear gene fragments were concatenated to generate a 2803-bp matrix in SequenceMatrix ([50]; see Supplementary Material 7). Using PartitionFinder version 2.1.1 [51], with the applied Bayesian information criterion (BIC) and greedy algorithm [52], the best substitution model and partitioning scheme were chosen for posterior phylogenetic analysis. As the best-fit partitioning scheme, PartitionFinder suggested two partitions (I: $18 \mathrm{~S}$ rRNA + 28S rRNA, II: ITS-1 + ITS2 ), and the best-fit model was GTR + I + G for both partitions. To obtain a set of Bayesian phylogenetic trees needed for the biogeographic analyses, the original matrix was analyzed using BEAST [53]. Four combinations of clock and tree priors were chosen and run in parallel: (a) a random local clock [54] with the coalescent tree prior, (b) a random local clock with speciation: Yule process as the tree prior, (c) a strict clock [55] with the coalescent tree prior, and (d) a strict clock with speciation: Yule process as the tree prior. Tree searches were run for 10 million generations, sampling the tree every 1000 steps. The trees were summarized with TREE ANNOTATOR software (distributed with BEAST), with the first 1000 trees removed. Tracer v1.3 [56] was then used to ensure that Markov chains had reached stationarity and to determine the correct 'burn-in' for the analysis, i.e., the first $10 \%$ of generations. The effective sample size values were greater than 200, and consensus trees were obtained after summarizing the resulting topologies and discarding the 'burn-in' data. All final consensus trees were viewed and visualized by FigTree v.1.4.3, available from https://tree.bio.ed.ac.uk/software/ figtree.

Consensus trees constructed from datasets a and $\mathrm{c}-\mathrm{d}$ shared identical topologies, whereas the tree based on dataset $\mathrm{b}$ was divergent from the remaining phylogenies. Consequently the first 9000 trees were removed from the set of trees $a$ and $b$, and the remaining 1000 trees were used in independent statistical dispersal-vicariance analyses (S-DIVA) [57, 58], implemented in RASP [59], 2020) with phylogenetic uncertainty considered in the calculations. Nebularmis species distributions were coded as broad but regionalized (e.g., old historical records of $N$. reticulatus outside of the Palearctic realm were discarded as being unreliable and most likely representing other Nebularmis species). The maximum number of areas at a node was set to 3 .

\section{Results}

\section{Taxonomic account}

Phylum: Tardigrada Doyère, 1840 [43].

Class: Heterotardigrada Marcus, 1927 [60].

Order: Echiniscoidea Richters, 1926 [61].

Family: Echiniscidae Thulin, 1928 [62].

Genus: Nebularmis Gąsiorek \& Michalczyk, 2020 in Gąsiorek et al. [26]

Amended diagnosis: Small- to medium-sized echiniscids with red granulate eyes. Long, rigid and thick buccal tube lacking stylet supports. Cirrophores of the cephalic cirri weakly outlined. Only cephalic cirri present. Two pairs of segmental plates and three median plates. Incisions (notches) on caudal plate. Pseudosegmental plates absent. Dorsal plate sculpture composed of an intracuticular sponge layer and large epicuticular, round or slightly hexagonal flat granules that may be connected by striae. Additionally, occasional sparse intracuticular

Table 2 GenBank accession numbers for the Nebularmis spp. analyzed in this work, bold font indicates new sequences

\begin{tabular}{llllll}
\hline Species & 18S rRNA & 28S rRNA & ITS-1 & ITS-2 & COI \\
\hline Nebularmis auratus sp. nov. & MW180881 & MW180904 & MW180893 & MW180889 & MW178237 \\
Nebularmis burmensis sp. nov. & MW180882-3 & MW180905-6 & MW180894-5 & MW180890-1 & MW178238 \\
Nebularmis cirinoi & MK529692, MW180884 & MK529722, MW180907 & - & MN271705, MW180892 & - \\
Nebularmis indicus sp. nov. & MW180885-6 & MW180908-9 & MW180896-7 & - & MW178239-41 \\
Nebularmis reticulatus & MK529693 & MK529723 & MN271708 & MN271700 & MN263917-8 \\
\hline
\end{tabular}


pillars and/or micropores may be visible in some portions of the dorsal plates, especially in the scapular plate. Ventral plates present, developed as subcephalic and genital plates. Ventral cuticle wrinkled. Long, sabre-like claws. Larvae and juveniles with minute sparse pores and densely arranged intracuticular pillars in the dorsal plates.

\section{Species: Nebularmis auratus sp. nov. Gąsiorek \& Michalczyk}

\section{ZooBank LSID: 5CD18D26-F072-4BD2-B221-43EODDE266B3}

Figures 1, 2, Table 3.

Description. Females (i.e., from the third instar onwards): Body dark orange to red and stout (Fig. 1), with large dark red eyes not visible after mounting in Hoyer's medium. Elongated, dactyloid cephalic papillae (secondary clavae) and reduced (primary) clavae (Fig. 2a). Peribuccal cirri with cirrophores. Cirrus $A$ short, with a weakly outlined cirrophore and distinctly thicker flagellum at its proximal end (Fig. 1, 2a).

Dorsal plates thick and well sclerotized, with an evident intracuticular sponge layer and rather tightly arranged flat epicuticular granules (Fig. 1, 2a). Granules are generally well-spaced on the scapular, median and centromedian portions of the paired segmental plates but merge extensively on the lateral portions of paired segmental plates (Fig. 1). The sculpture appears poorly developed and barely discernible under LCM. Cephalic plate small and similar in width to the evident rectangular cervical (neck) plate (Fig. 2a). Scapular plate with randomly distributed micropores. Median plates $\mathrm{m} 1$ and $\mathrm{m} 3$ unipartite, the latter reduced and weakly delineated from the caudal (terminal) plate. Median plate m2 bipartite, but its anterior portion reduced analogously to m3. Two pairs of large segmental plates are mostly uniform with no transverse belts. Caudal plate large, with short incisions (Fig. 1).

Ventral cuticle with a pair of subcephalic plates and a pair of densely granulated genital plates (Fig. 2c). Venter uniformly wrinkled. Pedal plates I-III absent, pedal plate IV unsculptured, with dentate collar IV (Fig. 2c). Weakly outlined pulvini present on all legs (Fig. 2b). A spine on leg I (Fig. 2b) and an elongated papilla on leg IV are present (Fig. 2c). Claws I-III shorter than claws IV. External claws on all legs spurless (Fig. 2b-c). Internal claws with spurs positioned at approximately $1 / 4-1 / 5$ of the claw height and divergent from the main branches; spurs usually with blunt distal ends (Fig. 2b-c).

Males: Not found.

Juveniles (i.e., second instar, sexually immature females): Without a gonopore and with a poreless scapular plate. Otherwise, same as adult females.

Larvae and eggs: Not found.

Type material: Holotype (adult + , slide MM.003.01) and 4 paratypes (2우, 2 juveniles; slides MM.003.02-5). All slides deposited in UJ.

Type locality: $17^{\circ} 28^{\prime} 55^{\prime \prime} \mathrm{N}, 97^{\circ} 05^{\prime} 53^{\prime \prime} \mathrm{E}, 1073 \mathrm{~m}$ asl; Myanmar, Mon, Eastern Yoma Mountains, Kyaiktiyo; moss from tree bark, mountain deciduous forest. This is the first record of tardigrades from Myanmar.

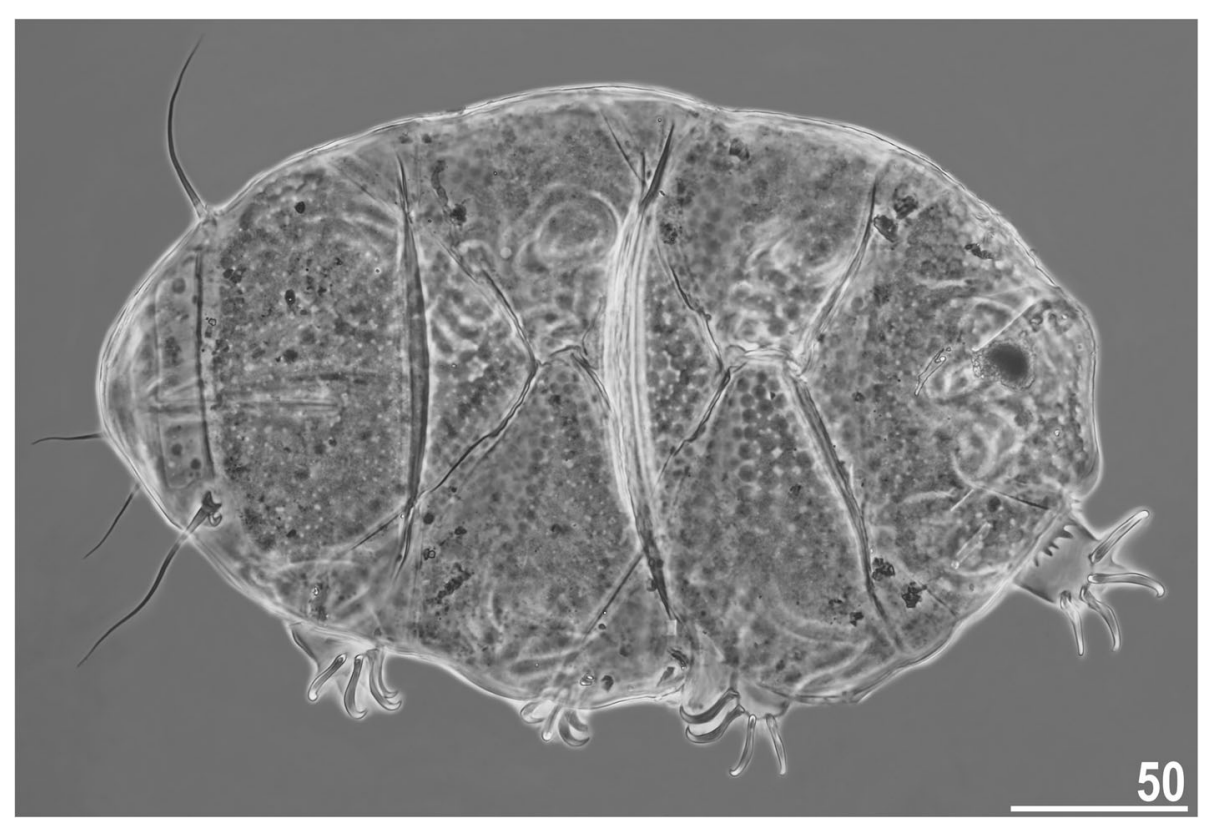

Fig. 1 Habitus of Nebularmis auratus sp. nov. (holotypic $q$ in dorsal view, PCM). Scale bar in $\mu m$ 

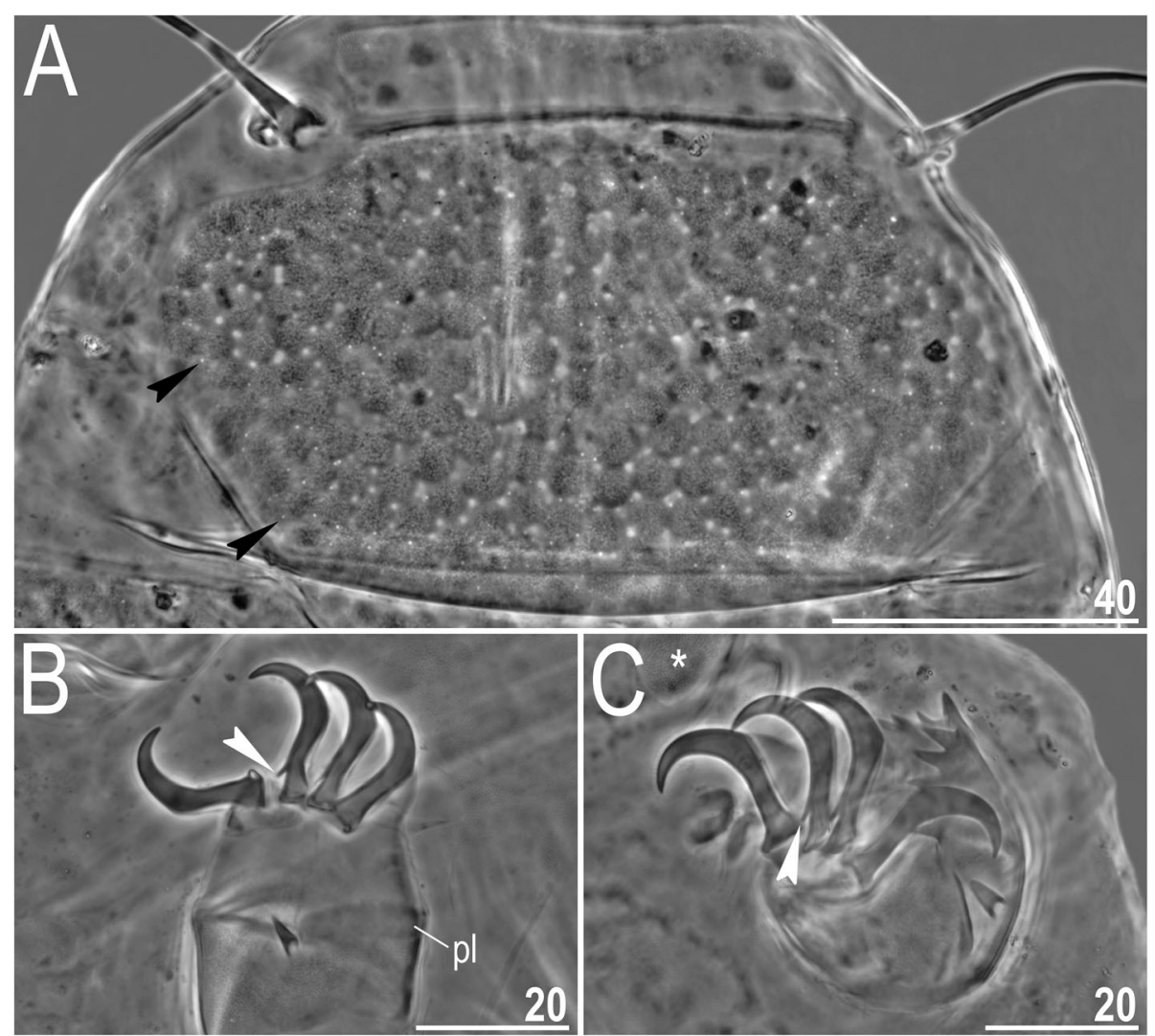

Fig. 2 Morphological details of Nebularmis auratus sp. nov. (PCM): A - scapular plate (note the irregularly distributed micropores), B - claws I, C claws IV. White arrowheads indicate characteristically blunt-ended primary spurs, black arrowheads - micropores, and asterisk - the genital plate, pl - pulvinus. Scale bars in $\mu \mathrm{m}$

Etymology: From Latin auratus = golden. The name refers to locus typicus, as Golden Rock is a typical Buddhist pilgrim destination in Myanmar. An adjective in the nominative singular.

Phylogenetic position. The species was inferred as the basal Nebularmis lineage in three of the performed analyses (see Fig. 17a for an exemplar tree). In the fourth Bayesian tree (combination c), N. auratus sp. nov. formed a clade with $N$. reticulatus (Fig. 17b). Both topologies were weakly supported. The $p$-distances in COI ranged between $14.8 \%(N$. burmensis sp. nov., MW178238) to $17.0 \%$ (N. reticulatus, MN263917).

\section{Nebularmis bhutanensis sp. nov. Veloso, Fontoura \& Gąsiorek}

\section{ZooBank LSID: 106DC9CF-6147-4866-BF6F-552455F3E8A5}

\section{Figures 3, 4, 5, Table 4}

Description. Females (i.e., from the third instar onwards): Body dark orangish-red and stout, with large dark red eyes not visible after mounting in Hoyer's medium. Large, swollen cephalic papillae (secondary clavae) and bluntly terminated (primary) clavae. Peribuccal cirri with short cirrophores. Cirrus $A$ short, with evident cirrophore and slightly thicker flagellum at its proximal end.

Dorsal plates thick and well sclerotized, with an evident intracuticular sponge layer and widely spaced flat epicuticular granules connected by striae of various thicknesses (Fig. 4). Granules merge partially in only lateral plate portions (Fig. 4a). Sculpture is obvious under LCM. Cephalic plate small and shorter than the evident rectangular cervical (neck) plate. Scapular plate with micropores distributed along its anterior and posterior edges. Median plates $\mathrm{m} 1$ and $\mathrm{m} 3$ unipartite, the latter extremely reduced and narrow. Median plate $\mathrm{m} 2$ bipartite, with the anterior portion reduced analogously to $\mathrm{m} 3$ (Fig. 4b). Two pairs of large segmental plates mostly uniform and with narrow transverse belts delimiting reduced anterior portions (Fig. 4c). Caudal plate large, with short incisions (Fig. 4d).

Ventral cuticle with a pair of subcephalic plates and a pair of densely granulated genital plates (Fig. 5d). Uniform ventral wrinkling present. Pedal plates I-IV sculptured and strongly granulated (Fig. 4c-d), plate IV with a dentate collar (Fig. 4d). Weakly outlined pulvini 
Table 3 Measurements [in $\mu \mathrm{m}$ ] of selected morphological structures of adult females and juveniles of $N$. auratus sp. nov. (type series) mounted in Hoyer's medium. Abbreviations: $s p$ - the proportion between the length of a given structure and the length of the scapular plate, ? - unknown

\begin{tabular}{|c|c|c|c|c|c|c|c|c|}
\hline \multirow[t]{2}{*}{ CHARACTERISTIC } & \multicolumn{2}{|c|}{ Holotype $(+)$} & \multicolumn{2}{|l|}{ q } & \multicolumn{2}{|c|}{ Juvenile 1} & \multicolumn{2}{|c|}{ Juvenile 2} \\
\hline & $\mu \mathrm{m}$ & $s p$ & $\mu \mathrm{m}$ & $s p$ & $\mu \mathrm{m}$ & $s p$ & $\mu \mathrm{m}$ & $s p$ \\
\hline Body length & 283 & 429 & 251 & 413 & 160 & 418 & 150 & 419 \\
\hline Scapular plate length & 66.0 & - & 60.8 & - & 38.3 & - & 35.8 & - \\
\hline \multicolumn{9}{|l|}{ Head appendage lengths } \\
\hline Cirrus internus & 22.0 & 33.3 & 18.0 & 29.6 & 9.4 & 24.5 & $?$ & $?$ \\
\hline Cephalic papilla & 10.4 & 15.8 & 9.0 & 14.8 & 6.7 & 17.5 & 5.3 & 14.8 \\
\hline Cirrus externus & 30.0 & 45.5 & 25.2 & 41.4 & 17.5 & 45.7 & 13.4 & 37.4 \\
\hline Clava & 6.4 & 9.7 & 8.2 & 13.5 & 6.5 & 17.0 & $?$ & $?$ \\
\hline Cirrus $A$ & 59.3 & 89.8 & 54.9 & 90.3 & $?$ & $?$ & 25.4 & 70.9 \\
\hline Cirrus A/body length ratio & $21 \%$ & - & $22 \%$ & - & $?$ & - & $17 \%$ & - \\
\hline \multicolumn{9}{|l|}{ Body appendage lengths } \\
\hline Spine on leg I length & 5.7 & 8.6 & 4.0 & 6.6 & 3.8 & 9.9 & 3.1 & 8.7 \\
\hline Papilla on leg IV length & 6.2 & 9.4 & 5.9 & 9.7 & 4.7 & 12.3 & 4.5 & 12.6 \\
\hline Number of teeth on the collar & 9 & - & 7 & - & 7 & - & 8 & - \\
\hline \multicolumn{9}{|l|}{ Claw I heights } \\
\hline Branch & 18.6 & 28.2 & 15.7 & 25.8 & 11.3 & 29.5 & 9.6 & 26.8 \\
\hline Spur & 3.1 & 4.7 & 3.0 & 4.9 & 1.6 & 4.2 & 2.0 & 5.6 \\
\hline Spur/branch height ratio & $17 \%$ & - & $19 \%$ & - & $14 \%$ & - & $21 \%$ & - \\
\hline \multicolumn{9}{|l|}{ Claw II heights } \\
\hline Branch & 17.0 & 25.8 & 15.3 & 25.2 & 10.2 & 26.6 & 8.6 & 24.0 \\
\hline Spur & $?$ & $?$ & 2.3 & 3.8 & 1.6 & 4.2 & 1.8 & 5.0 \\
\hline Spur/branch height ratio & $?$ & - & $15 \%$ & - & $16 \%$ & - & $21 \%$ & - \\
\hline \multicolumn{9}{|l|}{ Claw III heights } \\
\hline Branch & 17.2 & 26.1 & 14.9 & 24.5 & 9.8 & 25.6 & 8.3 & 23.2 \\
\hline Spur & 2.7 & 4.1 & 2.3 & 3.8 & 1.6 & 4.2 & 1.7 & 4.7 \\
\hline Spur/branch height ratio & $16 \%$ & - & $15 \%$ & - & $16 \%$ & - & $20 \%$ & - \\
\hline \multicolumn{9}{|l|}{ Claw IV heights } \\
\hline Branch & 22.2 & 33.6 & 19.2 & 31.6 & 12.4 & 32.4 & 10.2 & 28.5 \\
\hline Spur & 3.2 & 4.8 & $?$ & $?$ & 2.1 & 5.5 & 2.0 & 5.6 \\
\hline Spur/branch height ratio & $14 \%$ & - & $?$ & - & $17 \%$ & - & $20 \%$ & - \\
\hline
\end{tabular}

present on all legs. A spine on leg I and an elongated papilla on leg IV are present. Claws I-III are shorter than claws IV. External claws on all legs spurless (Fig. 5b, e). Internal claws with spurs positioned at approximately 1 / $4-2 / 5$ of the claw height and heteromorphic, more divergent from branches on claws IV than on claws I-III (Fig. 5e).

Males (i.e., from the third instar onwards): Qualitatively similar to females. Body ovoid (Fig. 3). Cephalic papillae swollen and very large, especially when compared to the (primary) clavae, with blunt ends (Fig. 5a). Gonopore circular, located between the trapezoidal granulated genital plates with a valvate slit separating them (Fig. 5c).
Juveniles, larvae and eggs: Not found.

Type material: Holotype (adult ${ }^{\text {, }}$ slide BT.001.01), allotype (adult $\hat{\partial}$, slide BT.001.02) and one paratype (adult $\widehat{\partial}$, slide AS.PE-H33). Holotype and allotype deposited in UJ, paratype deposited in UP.

Type locality: $37^{\circ} 29^{\prime} 32^{\prime \prime} \mathrm{N}, 89^{\circ} 21^{\prime} 49^{\prime \prime} \mathrm{E}, 3120 \mathrm{~m}$ asl; Bhutan, Eastern Himalayas, Paro Taktsang; moss from rock, pine forest. The first record of tardigrades from Bhutan.

Etymology: From Latin bhutanensis = inhabiting Bhutan. The name underlines terra typica. An adjective in the nominative singular.

Phylogenetic position. Unknown. The species has the most distinctive sculpture subtype within the entire 


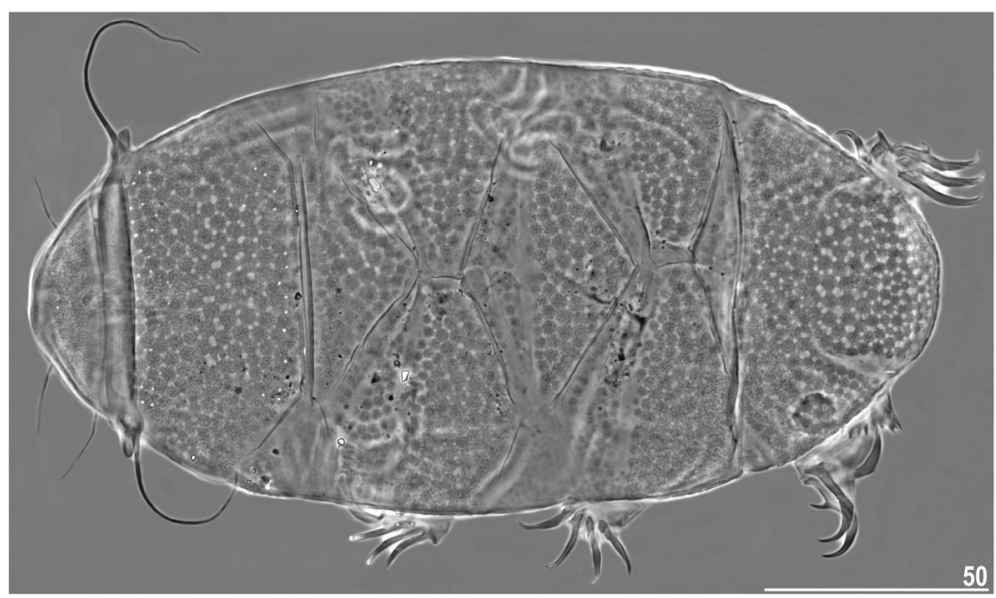

Fig. 3 Habitus of Nebularmis bhutanensis sp. nov. (allotypic ô in dorsal view, PCM). Scale bar in $\mu \mathrm{m}$

genus; thus, acquiring DNA sequences is important from a phylogenetic perspective.

\section{Nebularmis burmensis sp. nov. Gąsiorek \& Vončina ZooBank LSID: FCABDC67-E90D-4BB6-888A-0C518D3C6BC2} Figures 6, 7, 8, Table 5.

Description. Females (i.e., from the third instar onwards): Body dark orange and stout (Fig. 6a, 7), with large dark red eyes not visible after mounting in Hoyer's medium. Elongated, dactyloid cephalic papillae (secondary clavae) and reduced (primary) clavae (Fig. 6, 8a).
Peribuccal cirri with cirrophores. Cirrus $A$ short, with a weakly defined cirrophore and smooth proximal end of the flagellum that is approximately equal in width to its distal end (Fig. 6, 8a).

Dorsal plates thick and strongly sclerotized, with a poorly visible intracuticular sponge layer (Fig. 6b). Flat epicuticular granules well-spaced only in the scapular plate (Fig. 6b, 7, 8a-b) and anterior portions of the paired plates, in which the granules become pronounced convex bumps (Fig. 8d). In the remaining portions of the dorsal armor, the sculpture is poorly developed and
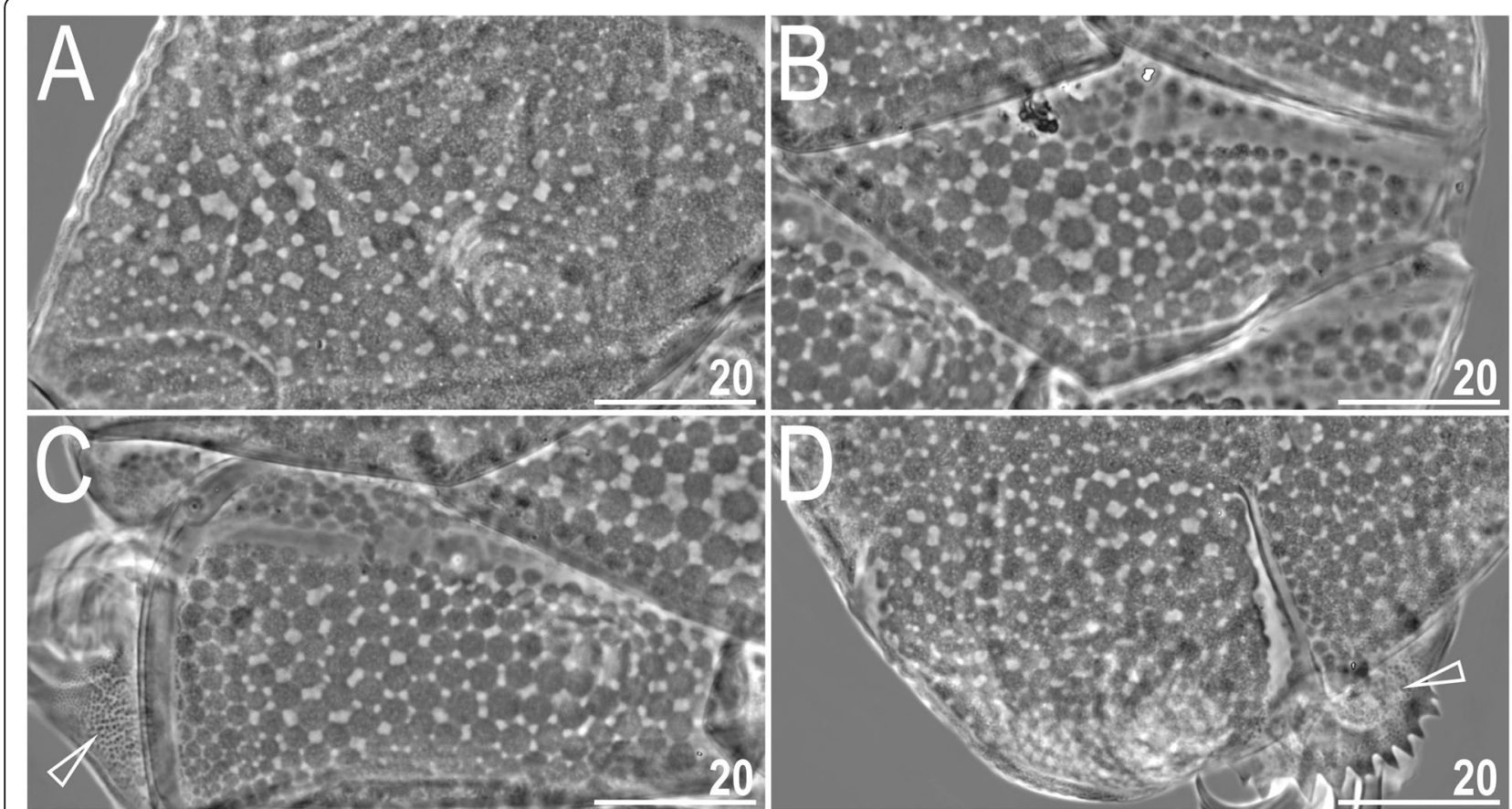

Fig. 4 Dorsal sculpturing of Nebularmis bhutanensis sp. nov. (holotypic $9, P C M$ ): A - scapular plate, B - median plate II, C - paired segmental plate II, D - caudal (terminal) plate. Arrowheads indicate conspicuous granulation on pedal platelets. Scale bars in $\mu \mathrm{m}$ 

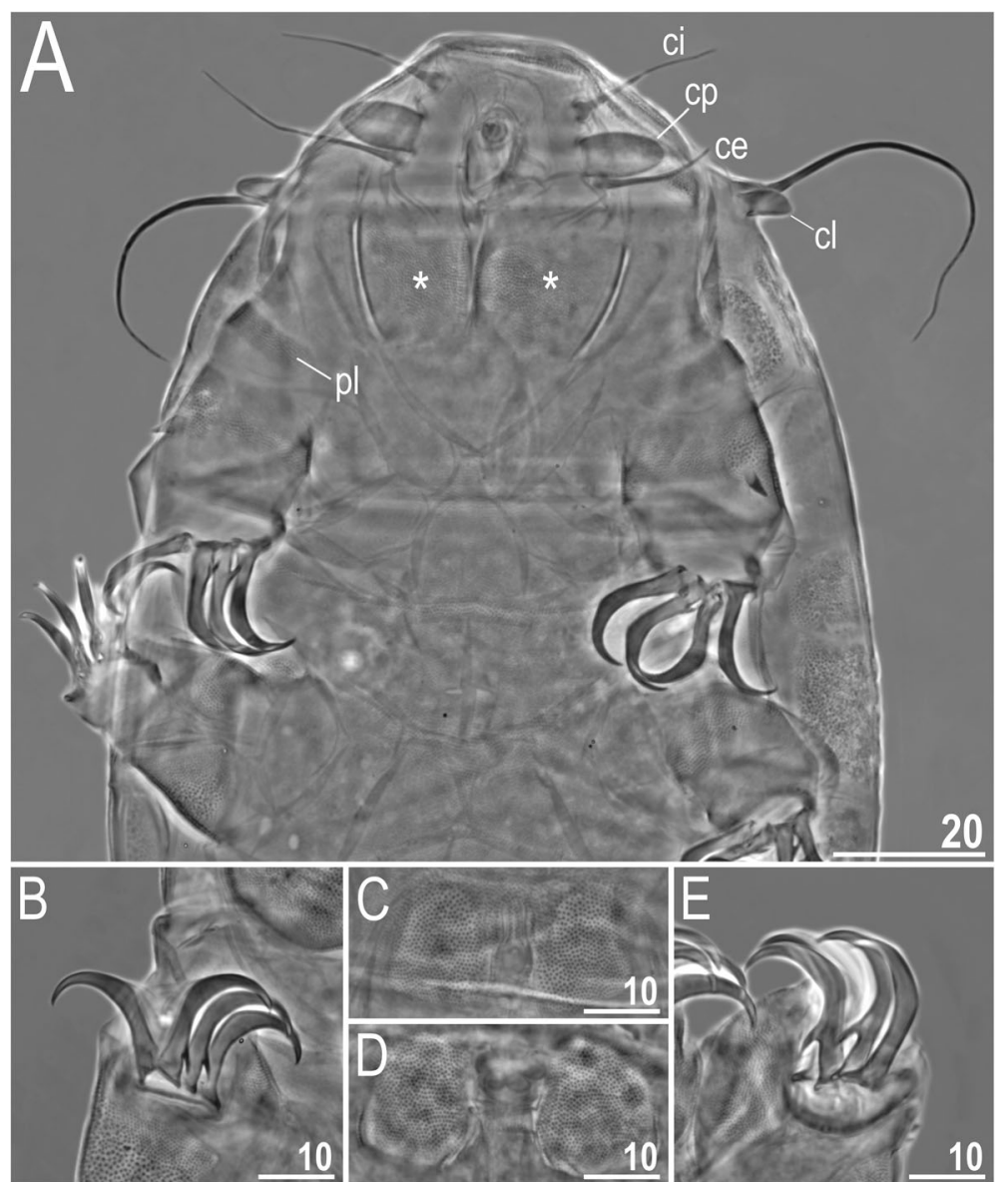

Fig. 5 Cephalic, ventral and limb structures of Nebularmis bhutanensis sp. nov. (PCM): A - anteroventral portion of the body (ce - cirrus externus, $\mathrm{ci}$ - cirrus internus, $\mathrm{cl}$ - primary clava, $\mathrm{cp}$ - cephalic papilla = secondary clava, $\mathrm{pl}$ - pulvinus, ${ }^{*}$ - subcephalic plate; note regular wrinkling, characteristic for the genus), B - claws II, C - genital plates and male gonopore, D - genital plates and female gonopore, E - claws IV. Scale bars in $\mu \mathrm{m}$

barely discernible under both LCM and SEM (Fig. 6a, 7, 8c). Cephalic plate is extremely small, with an anterior keel-shaped incision (Fig. 6a); the rectangular cervical (neck) plate is also poorly visible (Fig. 8a). Scapular plate without micropores (Fig. 6b, 8a-b). Median plates $\mathrm{m} 1$ and $\mathrm{m} 3$ unipartite, the latter rudimentary and weakly delineated from the caudal (terminal) plate (Fig. 6a, 7a). Median plate $\mathrm{m} 2$ bipartite, with the anterior portion reduced analogously to $\mathrm{m} 3$. Two pairs of large segmental plates, with evident transverse belts containing blunt hemispherical granules. Caudal plate large, with short incisions (Fig. 6a, 7b).

Ventral cuticle with a pair of subcephalic plates and a pair of genital plates. Regularly spaced ventral wrinkling present. Pedal plates I-III absent, pedal plate IV unsculptured, with dentate collar IV (Fig. 6a, 7b). Weakly outlined pulvini present on all legs (Fig. 7b). A spine on leg I and an elongated papilla on leg IV are present (Fig. 6a, 7b). Claws I-III shorter than claws IV.
External claws on all legs spurless (Fig. 6a, insert). Internal claws with short, divergent spurs positioned at approximately $1 / 4-1 / 5$ of the claw height.

Males: Not found.

Juveniles (i.e., second instar): Body $139 \mu \mathrm{m}$ long (scapular plate length $39.5 \mu \mathrm{m}$ ). Cephalic appendage lengths: cirrus internus $11.4 \mu \mathrm{m}$, cephalic papilla $5.6 \mu \mathrm{m}$, cirrus externus $12.8 \mu \mathrm{m}$, cirrus $A 23.0 \mu \mathrm{m}$. Body appendage lengths: spine I $2.9 \mu \mathrm{m}$, papilla IV $3.0 \mu \mathrm{m}$. Five teeth on the collar. Claw branch heights: 9.1-10.8 $\mu \mathrm{m}$ (spurs $1.7-1.9 \mu \mathrm{m})$. One qualitative difference with respect to adults is the lack of gonopore.

Larvae (i.e., first instar): Body $120 \mu \mathrm{m}$ long (scapular plate length $28.1 \mu \mathrm{m}$ ). Cephalic appendage lengths: cirrus internus $10.0 \mu \mathrm{m}$, cephalic papilla $4.6 \mu \mathrm{m}$, cirrus externus $11.6 \mu \mathrm{m}$, (primary) clava $5.0 \mu \mathrm{m}$, cirrus $A 18.9 \mu \mathrm{m}$. Body appendage lengths: spine I $1.7 \mu \mathrm{m}$, papilla IV $2.6 \mu \mathrm{m}$. Five teeth on the collar. Claw branch heights: 7.5$8.7 \mu \mathrm{m}$ (spurs 1.4-1.9 $\mu \mathrm{m}$ ). Gonopore and anus absent. 
Table 4 Measurements [in $\mu \mathrm{m}$ ] of selected morphological structures of adult $N$. bhutanensis sp. nov. (type series) mounted in Hoyer's medium. Abbreviations: sp - the proportion between the length of a given structure and the length of the scapular plate, ? - unknown

\begin{tabular}{|c|c|c|c|c|c|c|}
\hline \multirow[t]{2}{*}{ CHARACTERISTIC } & \multicolumn{2}{|c|}{ Holotype $(q)$} & \multicolumn{2}{|l|}{ 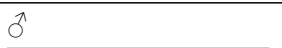 } & \multicolumn{2}{|c|}{ Allotype (ð) } \\
\hline & $\mu \mathrm{m}$ & $s p$ & $\mu \mathrm{m}$ & $s p$ & $\mu \mathrm{m}$ & $s p$ \\
\hline Body length & $241^{a}$ & 417 & $235^{a}$ & 467 & 202 & 493 \\
\hline Scapular plate length & 57.8 & - & 50.3 & - & 41.0 & - \\
\hline \multicolumn{7}{|l|}{ Head appendage lengths } \\
\hline Cirrus internus & 16.5 & 28.5 & 15.9 & 31.6 & 20.3 & 49.5 \\
\hline Cephalic papilla & 10.3 & 17.8 & 9.8 & 19.5 & 11.8 & 28.8 \\
\hline Cirrus externus & 22.6 & 39.1 & $?$ & $?$ & 28.0 & 68.3 \\
\hline Clava & 5.4 & 9.3 & 6.6 & 13.1 & 7.2 & 17.6 \\
\hline Cirrus $A$ & 54.9 & 95.0 & 51.1 & 101.6 & 52.8 & 128.8 \\
\hline Cirrus A/body length ratio & $23 \%$ & - & $22 \%$ & - & $26 \%$ & - \\
\hline \multicolumn{7}{|l|}{ Body appendage lengths } \\
\hline Spine on leg I length & 4.7 & 8.1 & 3.9 & 7.8 & 2.9 & 7.1 \\
\hline Papilla on leg IV length & 4.2 & 7.3 & 4.8 & 9.5 & 5.0 & 12.2 \\
\hline Number of teeth on the collar & 10 & - & 11.0 & - & 9 & - \\
\hline \multicolumn{7}{|l|}{ Claw I heights } \\
\hline Branch & 17.1 & 29.6 & 15.9 & 31.6 & 15.5 & 37.8 \\
\hline Spur & 3.2 & 5.5 & 3.1 & 6.2 & 3.0 & 7.3 \\
\hline Spur/branch height ratio & $19 \%$ & - & $19 \%$ & - & $19 \%$ & - \\
\hline \multicolumn{7}{|l|}{ Claw II heights } \\
\hline Branch & 17.3 & 29.9 & 15.2 & 30.2 & 14.5 & 35.4 \\
\hline Spur & 3.1 & 5.4 & 2.8 & 5.6 & 2.6 & 6.3 \\
\hline Spur/branch height ratio & $18 \%$ & - & $18 \%$ & - & $18 \%$ & - \\
\hline \multicolumn{7}{|l|}{ Claw III heights } \\
\hline Branch & 17.0 & 29.4 & 15.1 & 30.0 & 14.7 & 35.9 \\
\hline Spur & 3.0 & 5.2 & 2.4 & 4.8 & 2.6 & 6.3 \\
\hline Spur/branch height ratio & $18 \%$ & - & $16 \%$ & - & $18 \%$ & - \\
\hline \multicolumn{7}{|l|}{ Claw IV heights } \\
\hline Branch & 20.1 & 34.8 & 17.3 & 34.4 & 18.4 & 44.9 \\
\hline Spur & 5.2 & 9.0 & 3.4 & 6.8 & 4.9 & 12.0 \\
\hline Spur/branch height ratio & $26 \%$ & - & $20 \%$ & - & $27 \%$ & - \\
\hline
\end{tabular}

Eggs: Not found.

Type material: Holotype (adult + , slide MM.010.11) and 8 paratypes (6우, 1 juvenile, 1 larva; slides MM.010.08-10, 12-16). Slides MM.010.08-14 deposited in UJ, MM.010.15-16 deposited in UP.

Type locality: $20^{\circ} 38^{\prime} 28^{\prime \prime} \mathrm{N}, 97^{\circ} 04^{\prime} 14^{\prime \prime} \mathrm{E}, 1333 \mathrm{~m}$ asl; Myanmar, Shan, Shan Hills, Taunggyi, Kakku Pagodas; moss and lichen from tree bark, rural habitat. The first record of tardigrades from Myanmar.

Etymology: From Latin burmensis $=$ inhabiting Burma (the postcolonial name of Myanmar). The name underlines terra typica. An adjective in the nominative singular.
Phylogenetic position. The species was inferred to be a sister species to Nebularmis indicus sp. nov. (Fig. 17). The $p$-distances in COI ranged from 9.5\% ( $N$. indicus sp. nov., MW178240) to $14.8 \%$ (N. auratus sp. nov., MW178237).

Nebularmis cirinoi (Binda \& Pilato, 1993) [63]

Figures 9, 10, 11, Tables 6 and 7.

Description of Indomalayan populations. Females (i.e., from the third instar onwards): Body orange and stout (Fig. 9a), with large dark red eyes not visible after mounting in Hoyer's medium. Elongated, dactyloid cephalic papillae (secondary clavae) and blunt 

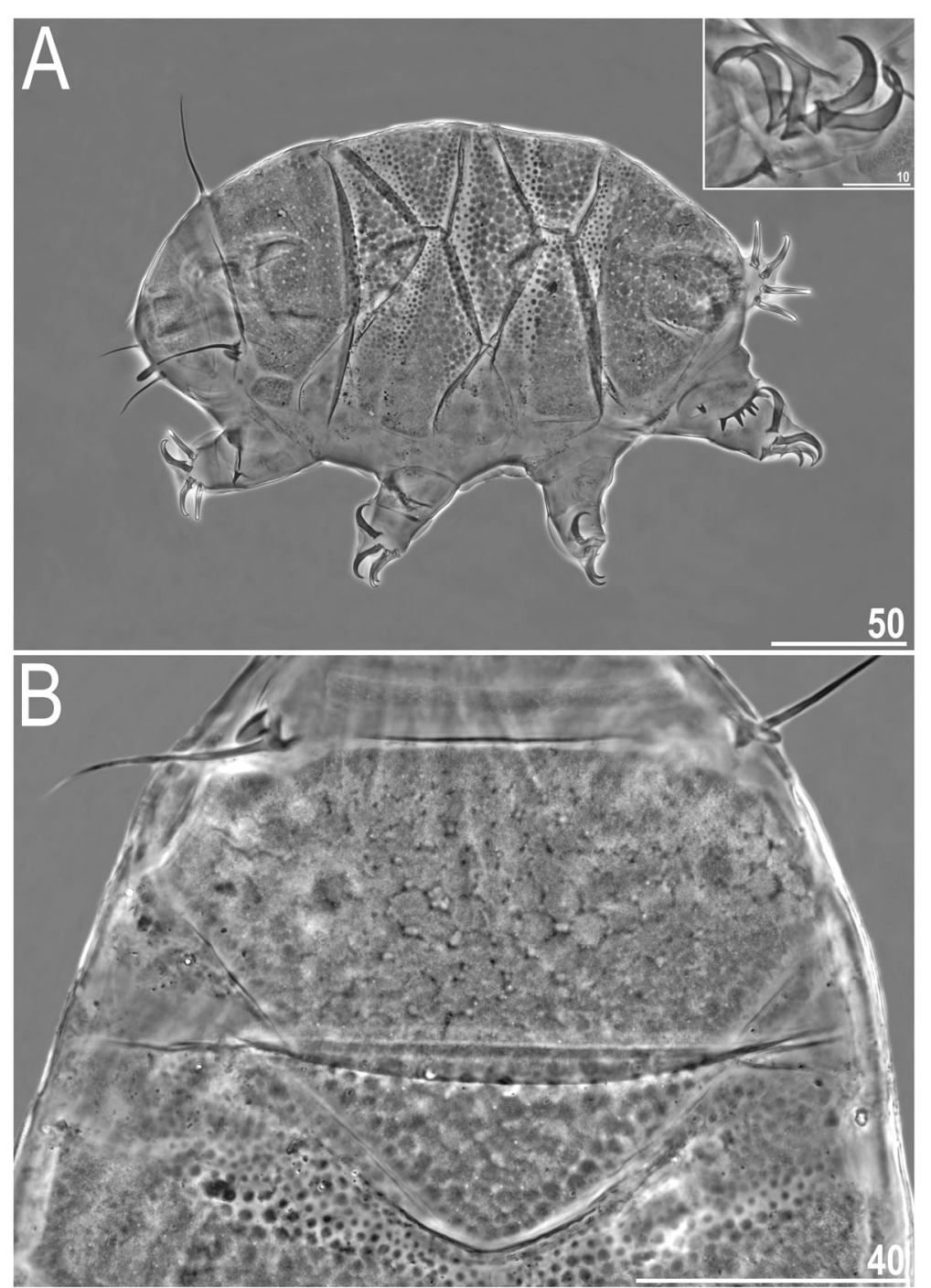

Fig. 6 Habitus of Nebularmis burmensis sp. nov. (PCM): A - holotypic $q$ in dorsolateral view (insert shows claws I), B - dorsal sculpturing of the anteriormost portion of the body. Scale bars in $\mu \mathrm{m}$

terminated (primary) clavae (Fig. 9a, 10). Peribuccal cirri with bulbous cirrophores (Fig. 10b). Cirrus $A$ short to medium in length, with the proximal end of the flagellum smooth and slightly thickened (Fig. 10a).

Dorsal plates thick and well sclerotized, with a dominant visible intracuticular sponge layer (Fig. 10a). Flat, circular epicuticular granules merging on almost all portions of the dorsal plates (Fig. 9a, 10a, 11a). Both cephalic and cervical (neck) plates poorly defined; scapular plate without micropores (Fig. 10a). Median plates $\mathrm{m} 1$ and $\mathrm{m} 3$ unipartite, the latter rudimentary and weakly delineated from the caudal (terminal) plate (Fig. 9a). Median plate $\mathrm{m} 2$ bipartite, with its anterior portion reduced analogously to $\mathrm{m} 3$. Two pairs of large segmental plates without transverse belts. Caudal plate of medium size, with short incisions.
Ventral cuticle with a pair of trapezoidal subcephalic plates (Fig. 10b) and a pair of genital plates. Uniform ventral wrinkling present. Pedal plates I-III absent, pedal plate IV weakly sculptured, with dentate collar IV (Fig. 11b). Weakly outlined pulvini present on all legs (Fig. 9a). A small spine on leg I and a conical papilla on leg IV are present (Fig. 9a, 10b, 11b). Claws I-III shorter than claws IV. External claws on all legs smooth. Heteromorphic internal claws with short spurs positioned at approximately $1 /$ $3-1 / 4$ of the claw height and more divergent from claw branches on leg IV than those on legs I-III (Fig. 11b).

Juveniles (i.e., second instar): Qualitatively similar to females. Epicuticular granules, with the exception of the central portions of median plates $\mathrm{m} 1-2$, completely 

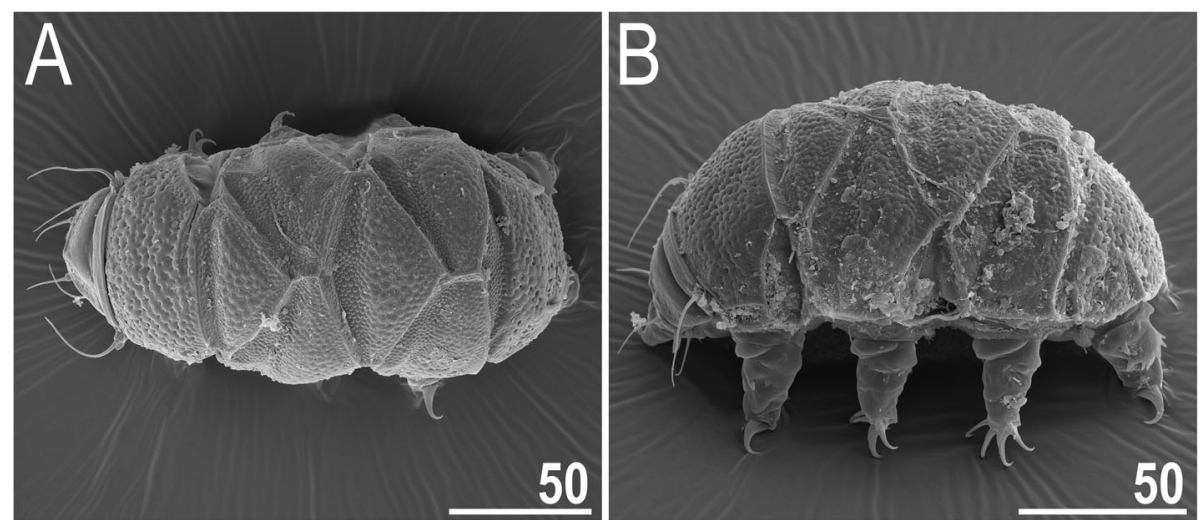

Fig. 7 Habitus of Nebularmis burmensis sp. nov. (SEM): A - dorsal view, B - dorsolateral view. Scale bars in $\mu$ m

merged, giving the dorsal plate surface a smooth appearance (Fig. 9b). Gonopore absent.

Larvae and eggs: Not found.

Material examined: Celebes: $12 q \circ, 4$ juveniles (slides ID.517.02, 05, 07, 12, 20-21, 24-28, 32, 37, 37-38, ID.518.05, 20), Tidore: 2 우 (slides ID.874.02, ID.882.07). All slides deposited in UJ.

Phylogenetic position. The species was inferred to be a sister taxon to the Nebularmis burmensis sp. nov. + Nebularmis indicus sp. nov. clade (Fig. 17).
Nebularmis indicus sp. nov. Gąsiorek, Ciosek \& Michalczyk ZooBank LSID: AEF9CF84-897A-4C08-8383-7E3B440EFA56

Figures 12, 13, 14, 15 and 16, Table 8.

Description. Females (i.e., from the third instar onwards): Body dark red and stout (Fig. 12a), with large ruby eyes not visible after mounting in Hoyer's medium. Elongated, dactyloid cephalic papillae (secondary clavae) and (primary) clavae. Peribuccal cirri with bulbous cirrophores. Cirrus $A$ short, with the proximal end of flagellum smooth and thickened (Fig. 12a).
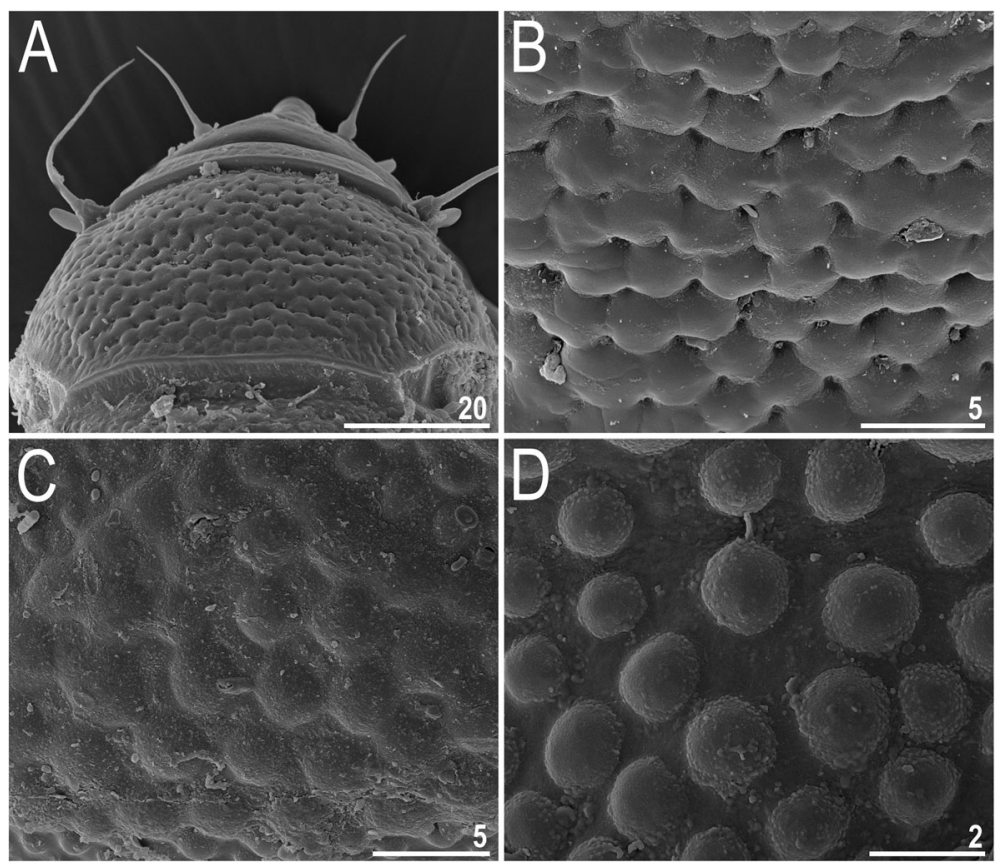

Fig. 8 Morphological details of Nebularmis burmensis sp. nov. (SEM): A - head, B - central portion of the scapular plate, C - central portion of the median plate I, D - epicuticular bumps covering the anterior portions of median and paired segmental plates in close-up. Scale bars in $\mu \mathrm{m}$ 
Table 5 Measurements [in $\mu \mathrm{m}$ ] of selected morphological structures of adult female N. burmensis sp. nov. (type series) mounted in Hoyer's medium. Abbreviations: $\mathrm{N}$ - number of specimens/structures measured, RANGE refers to the smallest and the largest structure among all the measured specimens; SD - standard deviation; sp - the proportion between the length of a given structure and the length of the scapular plate

\begin{tabular}{|c|c|c|c|c|c|c|c|c|c|c|c|c|c|}
\hline \multirow{3}{*}{$\begin{array}{l}\text { CHARACTERISTIC } \\
\text { Body length }\end{array}$} & \multirow{3}{*}{$\begin{array}{l}\mathbf{N} \\
7\end{array}$} & \multicolumn{6}{|c|}{ RANGE } & \multicolumn{2}{|c|}{ MEAN } & \multicolumn{2}{|l|}{ SD } & \multicolumn{2}{|c|}{ Holotype } \\
\hline & & \multicolumn{3}{|l|}{$\mu \mathrm{m}$} & \multicolumn{3}{|l|}{$s p$} & \multirow{2}{*}{$\begin{array}{l}\boldsymbol{\mu m} \\
227\end{array}$} & \multirow{2}{*}{$\begin{array}{l}\boldsymbol{s p} \\
432\end{array}$} & \multirow{2}{*}{$\begin{array}{l}\boldsymbol{\mu m} \\
6\end{array}$} & \multirow{2}{*}{$\frac{\boldsymbol{s p}}{21}$} & \multirow{2}{*}{$\begin{array}{l}\boldsymbol{\mu m} \\
227\end{array}$} & \multirow{2}{*}{$\frac{\boldsymbol{s p}}{440}$} \\
\hline & & 217 & - & 236 & 407 & - & 465 & & & & & & \\
\hline Scapular plate length & 7 & 49.6 & - & 55.6 & & - & & 52.6 & - & 2.2 & - & 51.6 & - \\
\hline \multicolumn{14}{|l|}{ Head appendage lengths } \\
\hline Cirrus internus & 7 & 15.3 & - & 18.5 & 30.6 & - & 34.8 & 17.3 & 32.8 & 1.4 & 1.7 & 17.0 & 32.9 \\
\hline Cephalic papilla & 7 & 6.8 & - & 8.6 & 13.0 & - & 16.8 & 7.9 & 15.1 & 0.6 & 1.1 & 8.0 & 15.5 \\
\hline Cirrus externus & 7 & 20.6 & - & 25.0 & 38.7 & - & 47.1 & 22.8 & 43.4 & 1.7 & 3.2 & 23.2 & 45.0 \\
\hline Clava & 7 & 5.9 & - & 7.8 & 11.8 & - & 14.0 & 6.8 & 12.9 & 0.6 & 0.8 & 7.1 & 13.8 \\
\hline Cirrus A & 7 & 36.8 & - & 43.5 & 70.1 & - & 79.6 & 39.6 & 75.3 & 2.1 & 3.3 & 38.9 & 75.4 \\
\hline Cirrus A/body length ratio & 7 & $16 \%$ & - & $19 \%$ & & - & & $17 \%$ & - & $1 \%$ & - & $17 \%$ & - \\
\hline \multicolumn{14}{|l|}{ Body appendage lengths } \\
\hline Spine on leg I length & 7 & 4.0 & - & 5.0 & 7.9 & - & 9.4 & 4.5 & 8.6 & 0.3 & 0.6 & 4.7 & 9.1 \\
\hline Papilla on leg IV length & 7 & 4.0 & - & 4.9 & 8.0 & - & 9.5 & 4.6 & 8.7 & 0.3 & 0.6 & 4.7 & 9.1 \\
\hline Number of teeth on the collar & 7 & 8 & - & 10 & & - & & 9.0 & - & 0.6 & - & 10 & - \\
\hline \multicolumn{14}{|l|}{ Claw I heights } \\
\hline Branch & 7 & 14.6 & - & 16.5 & 26.6 & - & 29.8 & 15.0 & 28.5 & 0.7 & 1.2 & 14.6 & 28.3 \\
\hline Spur & 7 & 1.9 & - & 2.6 & 3.4 & - & 5.0 & 2.2 & 4.2 & 0.3 & 0.5 & 2.2 & 4.3 \\
\hline Spur/branch height ratio & 7 & $13 \%$ & - & $18 \%$ & & - & & $15 \%$ & - & $2 \%$ & - & $15 \%$ & - \\
\hline \multicolumn{14}{|l|}{ Claw II heights } \\
\hline Branch & 7 & 14.1 & - & 15.9 & 25.7 & - & 29.2 & 14.6 & 27.7 & 0.6 & 1.2 & 14.2 & 27.5 \\
\hline Spur & 6 & 1.8 & - & 2.1 & 3.3 & - & 4.1 & 2.0 & 3.8 & 0.1 & 0.3 & 2.1 & 4.1 \\
\hline Spur/branch height ratio & 6 & $13 \%$ & - & $15 \%$ & & - & & $14 \%$ & - & $1 \%$ & - & $15 \%$ & - \\
\hline \multicolumn{14}{|l|}{ Claw III heights } \\
\hline Branch & 7 & 13.8 & - & 16.4 & 26.0 & - & 31.0 & 15.0 & 28.5 & 1.0 & 1.8 & 15.0 & 29.1 \\
\hline Spur & 5 & 1.8 & - & 2.7 & 3.4 & - & 4.9 & 2.1 & 3.9 & 0.4 & 0.6 & 2.0 & 3.9 \\
\hline Spur/branch height ratio & 5 & $12 \%$ & - & $16 \%$ & & - & & $14 \%$ & - & $2 \%$ & - & $13 \%$ & - \\
\hline \multicolumn{14}{|l|}{ Claw IV heights } \\
\hline Branch & 7 & 18.1 & - & 20.5 & 32.9 & - & 37.1 & 18.6 & 35.5 & 0.9 & 1.6 & 18.6 & 36.0 \\
\hline Spur & 3 & 2.7 & - & 3.0 & 5.1 & - & 5.8 & 2.9 & 5.4 & 0.2 & 0.4 & 3.0 & 5.8 \\
\hline Spur/branch height ratio & 3 & $15 \%$ & - & $16 \%$ & & - & & $16 \%$ & - & $1 \%$ & - & $16 \%$ & - \\
\hline
\end{tabular}

Dorsal plates thick and strongly sclerotized, with a poorly visible intracuticular sponge layer. Epicuticular granules well separated on all plates except for the lateral portions of the paired segmental plates; granules connected by thick striae. Granules are raised, leaving deep pseudopore-like areas between them (Fig. 12a, 15). Cephalic plate large, adjacent to an evident rectangular cervical (neck) plate. Scapular plate without micropores (Fig. 15a). Median plates $\mathrm{m} 1$ unipartite and $\mathrm{m} 2$ bipartite, with the anterior portion extremely reduced. Median plate $\mathrm{m} 3$ rudimentary and smooth centrally. Two pairs of large segmental plates with evident but thin transverse belts. Caudal plate large, with short sclerotized incisions (Fig. 12a).

Ventral cuticle with a pair of subcephalic plates and a pair of trapezoidal genital plates. Uniform ventral wrinkling present. Pedal plates I-III absent, pedal plate IV unsculptured. Leg IV with dentate collar. Pulvini light, clearly visible only under NCM. Spine on leg I (Fig. 12a) and an elongated papilla on leg IV (Fig. 12b) are present. Claws I-III shorter than claws IV. External claws on all legs spurless. Internal claws with short spurs positioned at approximately $1 / 4$ of the claw height and only slightly divergent from main branches. 

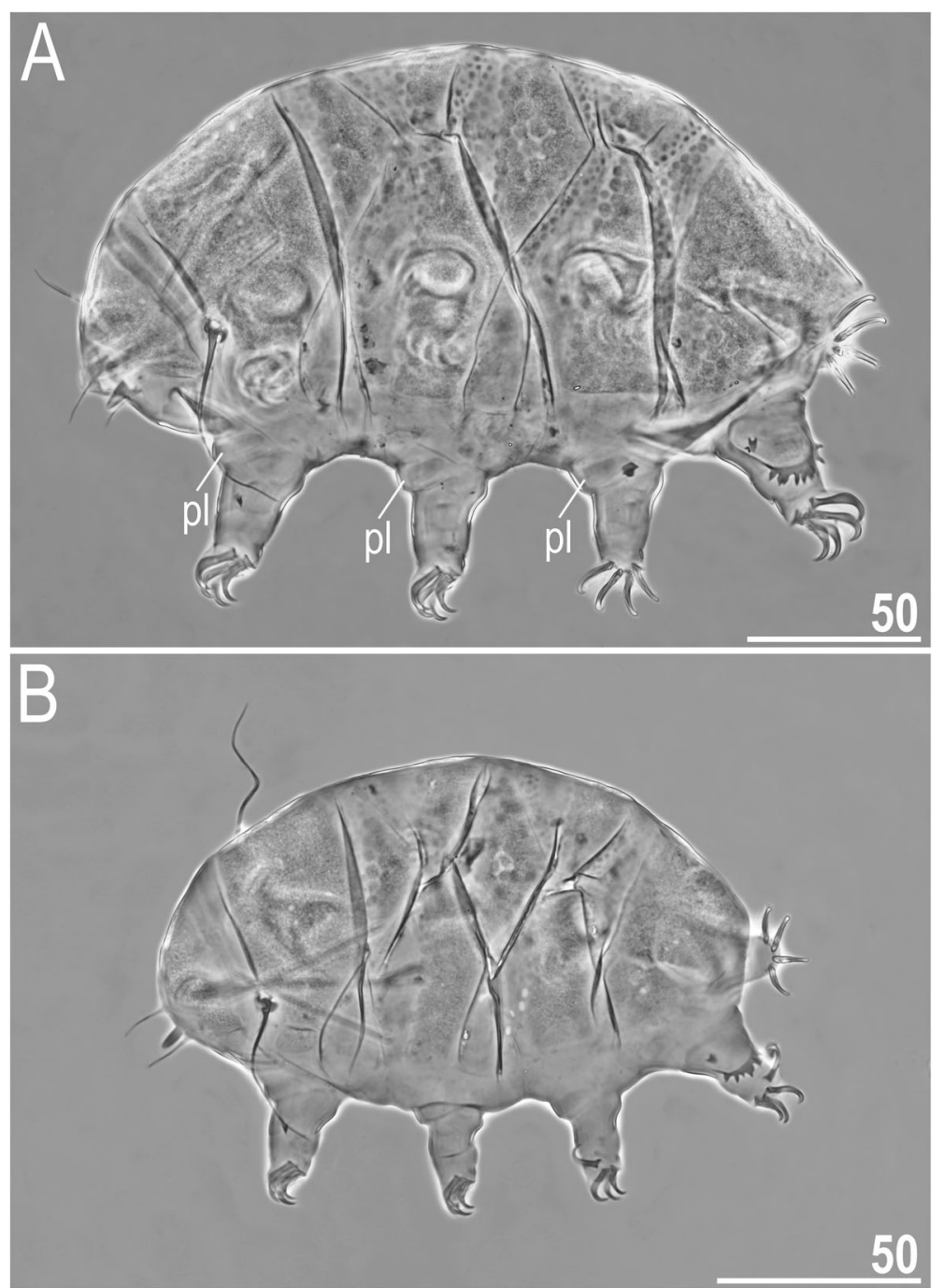

Fig. 9 Habitus of Nebularmis cirinoi (PCM): A - + in dorsolateral view (pl - pulvini), B - juvenile in dorsolateral view. Scale bars in $\mu m$

Males (i.e., from the third instar onwards): Body small and less plump than that of female (Fig. 12). Dorsal sculpturing identical to that in females (Fig. 13a, 14a). Gonopore ovoid, with a semicircular slit and two anteriorly directed and thickened valves (Fig. 13b, 14b).

Juveniles (i.e., the second instar): Gonopore absent; the remaining traits identical to adults.

Larvae (i.e., the first instar): Median plate m3 undeveloped. Dorsal sculpturing disparate from older life stages; belts of endocuticular pillars arranged in an ornamented pattern, especially in the central portions of plates (Fig. 16). Epicuticular granules absent. Gonopore and anus absent.

Eggs: Up to four dark orange eggs in an exuvia.

Type material: Holotype (adult +, slide IN.040.01), allotype (adult $\hat{\sigma}$, slide IN.041.01) and 4 paratypes (1q, 10 , 1 juvenile, 1 larva; slides IN.040.02-03, IN.075.01, IN.076.01). Hologenophores: two specimens of unidentified sex (IN.040.04, IN.076.02), one exuvia containing eggs (IN.075.02). Slides IN.040.02-03 deposited in UP, and the remaining slides deposited in UJ.

Type locality: $15^{\circ} 05^{\prime} 44^{\prime \prime} \mathrm{N}, 74^{\circ} 12^{\prime} 41^{\prime \prime} \mathrm{E}, 77 \mathrm{~m}$ asl; India, Goa, Western Ghats, Netravali; moss from tree bark, spice plantation.

Additional locality: $14^{\circ} 58^{\prime} 01^{\prime \prime} \mathrm{N}, 74^{\circ} 09^{\prime} 30^{\prime \prime} \mathrm{E}, 100 \mathrm{~m}$ asl; India, Goa, Western Ghats, Cotigao; moss from tree bark in forest canopy, moist deciduous forest.

Etymology: From Latin indicus = Indian. The name refers to the Indian subcontinent, where the new species was found. An adjective in the nominative singular.

Phylogenetic position. The species was inferred to be a sister species to Nebularmis burmensis sp. nov. (Fig. 17). The $p$-distances in COI ranged from 9.5\% (N. burmensis sp. nov., MW178238) to $16.4 \%$ (N. reticulatus, MN263917). Intraspecific variability ranged from 1.6 to $5.1 \%$. It has been demonstrated that 

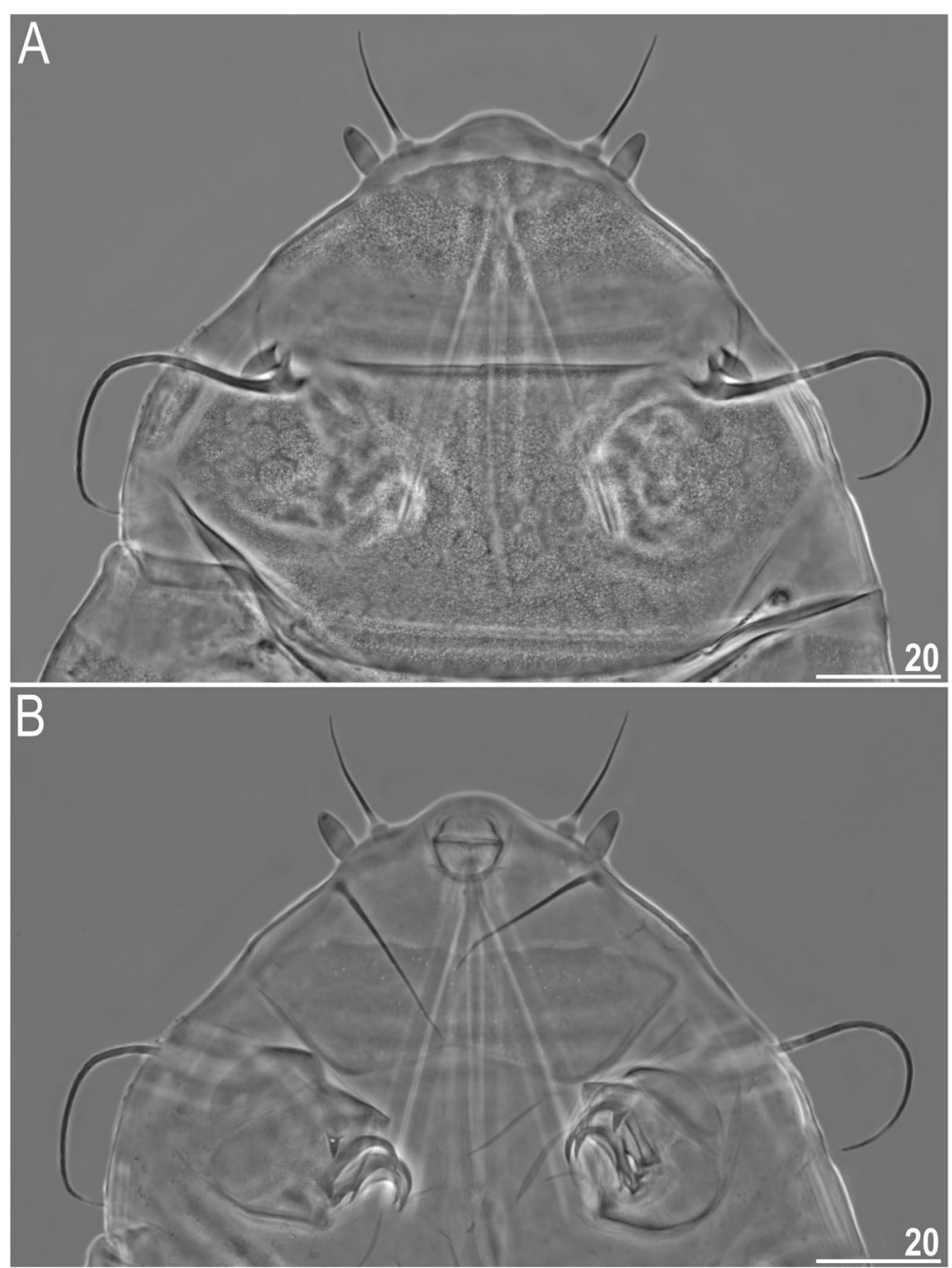

Fig. 10 Cephalic and ventral structures of Nebularmis cirinoi (PCM): A - anterodorsal portion of the body, B - anteroventral portion of the body (note a pair of large trapezoidal subcephalic plates with irregularly distributed micropores). Scale bars in $\mu m$
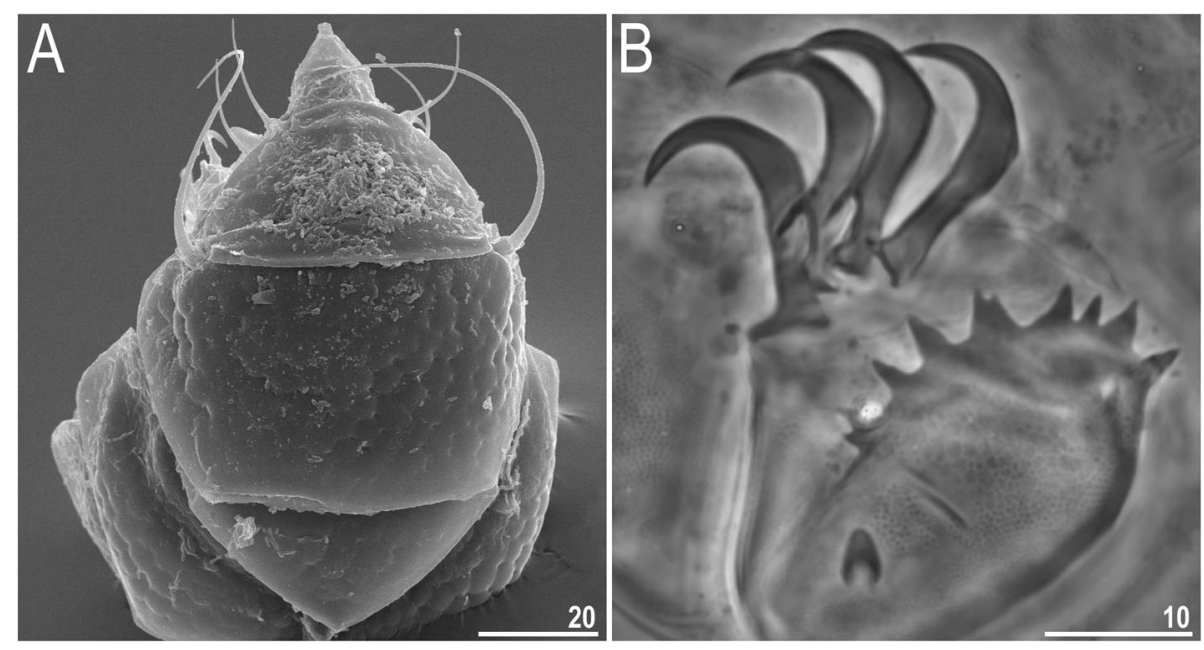

Fig. 11 Morphological details of Nebularmis cirinoi: A - anterodorsal portion of the body (SEM), B - claws IV. Scale bars in $\mu \mathrm{m}$ 
Table 6 Measurements [in $\mu \mathrm{m}$ ] of selected morphological structures of adult females of N. cirinoi (Indomalayan specimens) mounted in Hoyer's medium. Abbreviations: N - number of specimens/structures measured, RANGE refers to the smallest and the largest structure among all measured specimens; SD - standard deviation; sp - the proportion between the length of a given structure and the length of the scapular plate; ? - unknown

\begin{tabular}{|c|c|c|c|c|c|c|c|c|c|c|c|}
\hline \multirow[t]{2}{*}{ CHARACTERISTIC } & \multirow[t]{2}{*}{$\mathbf{N}$} & \multicolumn{6}{|c|}{ RANGE } & \multicolumn{2}{|c|}{ MEAN } & \multicolumn{2}{|l|}{ SD } \\
\hline & & $\mu \mathrm{m}$ & & & $s p$ & & & $\mu \mathrm{m}$ & $s p$ & $\mu \mathrm{m}$ & $s p$ \\
\hline Body length & 9 & 200 & - & 252 & 384 & - & 446 & 220 & 416 & 18 & 22 \\
\hline Scapular plate length & 9 & 45.7 & - & 62.5 & & - & & 53.1 & - & 4.4 & - \\
\hline \multicolumn{12}{|l|}{ Head appendage lengths } \\
\hline Cirrus internus & 8 & 17.4 & - & 25.8 & 36.2 & - & 47.8 & 20.8 & 40.0 & 2.4 & 3.9 \\
\hline Cephalic papilla & 9 & 8.2 & - & 9.7 & 14.9 & - & 19.3 & 9.2 & 17.4 & 0.5 & 1.4 \\
\hline Cirrus externus & 9 & 20.1 & - & 26.7 & 39.7 & - & 49.4 & 23.9 & 45.2 & 2.1 & 3.5 \\
\hline Clava & 9 & 4.5 & - & 8.2 & 8.3 & - & 14.9 & 6.9 & 13.0 & 1.1 & 2.2 \\
\hline Cirrus A & 7 & 64.8 & - & 72.2 & 112.8 & - & 133.7 & 68.1 & 125.7 & 2.6 & 7.0 \\
\hline Cirrus A/Body length ratio & 7 & $28 \%$ & - & $35 \%$ & & - & & $30 \%$ & - & $2 \%$ & - \\
\hline \multicolumn{12}{|l|}{ Body appendage lengths } \\
\hline Spine on leg I length & 8 & 2.0 & - & 4.6 & 4.4 & - & 7.5 & 3.5 & 6.6 & 0.8 & 1.1 \\
\hline Papilla on leg IV length & 8 & 3.6 & - & 5.1 & 6.2 & - & 9.6 & 4.3 & 8.2 & 0.5 & 1.0 \\
\hline Number of teeth on the collar & 9 & 8 & - & 11 & & - & & 9.0 & - & 1.1 & - \\
\hline \multicolumn{12}{|l|}{ Claw I heights } \\
\hline Branch & 9 & 12.6 & - & 15.3 & 24.5 & - & 28.1 & 14.0 & 26.5 & 0.7 & 1.1 \\
\hline Spur & 8 & 3.1 & - & 4.1 & 5.1 & - & 7.6 & 3.5 & 6.5 & 0.4 & 0.8 \\
\hline Spur/branch height ratio & 8 & $21 \%$ & - & $29 \%$ & & - & & $25 \%$ & - & $3 \%$ & - \\
\hline \multicolumn{12}{|l|}{ Claw II heights } \\
\hline Branch & 9 & 12.4 & - & 14.4 & 23.0 & - & 27.1 & 13.3 & 25.1 & 0.6 & 1.3 \\
\hline Spur & 8 & 2.8 & - & 4.0 & 5.4 & - & 6.9 & 3.2 & 6.0 & 0.4 & 0.5 \\
\hline Spur/branch height ratio & 8 & $22 \%$ & - & $28 \%$ & & - & & $24 \%$ & - & $2 \%$ & - \\
\hline \multicolumn{12}{|l|}{ Claw III heights } \\
\hline Branch & 9 & 12.3 & - & 14.3 & 22.9 & - & 27.8 & 13.3 & 25.1 & 0.6 & 1.6 \\
\hline Spur & 9 & 2.6 & - & 3.6 & 5.0 & - & 7.2 & 3.2 & 6.1 & 0.3 & 0.8 \\
\hline Spur/branch height ratio & 9 & $21 \%$ & - & $27 \%$ & & - & & $24 \%$ & - & $2 \%$ & - \\
\hline \multicolumn{12}{|l|}{ Claw IV heights } \\
\hline Branch & 9 & 15.2 & - & 17.4 & 26.6 & - & 33.7 & 16.2 & 30.7 & 0.7 & 2.3 \\
\hline Spur & 1 & 4.5 & - & 4.5 & 7.2 & - & 7.2 & 4.5 & 7.2 & $?$ & $?$ \\
\hline Spur/branch height ratio & 1 & $27 \%$ & - & $27 \%$ & & - & & $27 \%$ & - & $?$ & - \\
\hline
\end{tabular}

thresholds used in determining barcoding gaps differ greatly between various animal groups [64], often exceeding the arbitrary $3 \%$ COI threshold proposed by some studies and commonly applied in DNA-based taxonomy. Our experience suggests that there could be no universal thresholds for all tardigrade groups and that in some of them, the threshold might be higher than that in others [65]. Importantly, systematic testing of intra- and interspecific genetic distances among tardigrade species from different evolutionary lineages is yet to be performed.
See Table 9 for interspecific comparisons among Nebularmis (i.e., multiple differential phenotypic descriptions).

\section{Phylogeography}

Two topologies were observed in the Bayesian analyses based on four datasets (see Materials and methods): $((((N$. auratus sp. nov. $(((N$. reticulatus $((N$. cirinoi $(N$. burmensis sp. nov. $+N$. indicus sp. nov. $)))$ (Fig. 17a) and $(((N$. reticulatus $+N$. auratus sp. nov. $)+((N$. cirinoi (N. burmensis sp. nov. $+N$. indicus sp. nov.))) (Fig. 17b). 
Table 7 Measurements [in $\mu \mathrm{m}$ ] of selected morphological structures of juveniles of N. cirinoi (Indomalayan specimens) mounted in Hoyer's medium. Abbreviations: $\mathrm{N}$ - number of specimens/structures measured, RANGE refers to the smallest and the largest structure among all measured specimens; SD - standard deviation; $s p$ - the proportion between the length of a given structure and the length of the scapular plate; ? - unknown

\begin{tabular}{|c|c|c|c|c|c|c|c|c|c|c|c|}
\hline \multirow[t]{2}{*}{ CHARACTERISTIC } & \multirow[t]{2}{*}{$\mathbf{N}$} & \multicolumn{6}{|c|}{ RANGE } & \multicolumn{2}{|c|}{ MEAN } & \multicolumn{2}{|l|}{ SD } \\
\hline & & $\mu \mathrm{m}$ & & & $s p$ & & & $\mu \mathrm{m}$ & $s p$ & $\mu \mathrm{m}$ & $s p$ \\
\hline Body length & 5 & 145 & - & 192 & 374 & - & 443 & 172 & 406 & 19 & 27 \\
\hline Scapular plate length & 5 & 35.0 & - & 51.3 & & - & & 42.7 & - & 5.8 & - \\
\hline \multicolumn{12}{|l|}{ Head appendage lengths } \\
\hline Cirrus internus & 5 & 12.8 & - & 19.6 & 36.6 & - & 41.0 & 16.5 & 38.6 & 2.5 & 1.7 \\
\hline Cephalic papilla & 5 & 7.0 & - & 7.9 & 15.2 & - & 20.0 & 7.5 & 17.7 & 0.4 & 2.0 \\
\hline Cirrus externus & 5 & 14.5 & - & 21.8 & 41.4 & - & 48.1 & 19.2 & 44.9 & 2.8 & 2.8 \\
\hline Clava & 5 & 5.1 & - & 6.9 & 12.8 & - & 15.3 & 6.0 & 14.1 & 0.7 & 1.0 \\
\hline Cirrus A & 5 & 41.2 & - & 67.0 & 117.7 & - & 130.6 & 54.3 & 126.8 & 9.2 & 5.4 \\
\hline Cirrus A/body length ratio & 5 & $28 \%$ & - & $35 \%$ & & - & & $31 \%$ & - & $3 \%$ & - \\
\hline \multicolumn{12}{|l|}{ Body appendage lengths } \\
\hline Spine on leg I length & 5 & 2.6 & - & 3.4 & 6.0 & - & 8.1 & 2.9 & 7.0 & 0.3 & 1.0 \\
\hline Papilla on leg IV length & 5 & 2.9 & - & 5.0 & 8.3 & - & 9.7 & 3.8 & 8.9 & 0.8 & 0.8 \\
\hline Number of teeth on the collar & 5 & 6 & - & 9 & & - & & 7.6 & - & 1.1 & - \\
\hline \multicolumn{12}{|l|}{ Claw I heights } \\
\hline Branch & 5 & 9.2 & - & 13.8 & 26.3 & - & 30.1 & 11.8 & 27.6 & 1.7 & 1.5 \\
\hline Spur & 5 & 2.0 & - & 3.8 & 5.7 & - & 7.4 & 2.9 & 6.8 & 0.6 & 0.7 \\
\hline Spur/branch height ratio & 5 & $22 \%$ & - & $28 \%$ & & - & & $25 \%$ & - & $3 \%$ & - \\
\hline \multicolumn{12}{|l|}{ Claw II heights } \\
\hline Branch & 5 & 9.3 & - & 12.7 & 24.3 & - & 26.8 & 11.0 & 25.8 & 1.2 & 1.2 \\
\hline Spur & 5 & 2.1 & - & 3.5 & 5.7 & - & 7.3 & 2.8 & 6.6 & 0.5 & 0.7 \\
\hline Spur/branch height ratio & 5 & $23 \%$ & - & $28 \%$ & & - & & $26 \%$ & - & $2 \%$ & - \\
\hline \multicolumn{12}{|l|}{ Claw III heights } \\
\hline Branch & 5 & 8.8 & - & 12.9 & 23.1 & - & 25.4 & 10.6 & 24.8 & 1.5 & 0.9 \\
\hline Spur & 5 & 2.1 & - & 3.0 & 4.8 & - & 7.1 & 2.7 & 6.3 & 0.4 & 1.0 \\
\hline Spur/branch height ratio & 5 & $21 \%$ & - & $28 \%$ & & - & & $25 \%$ & - & $3 \%$ & - \\
\hline \multicolumn{12}{|l|}{ Claw IV heights } \\
\hline Branch & 5 & 9.9 & - & 15.0 & 28.3 & - & 30.6 & 12.7 & 29.6 & 1.8 & 0.9 \\
\hline Spur & 1 & 3.2 & - & 3.2 & 7.3 & - & 7.3 & 3.2 & 7.3 & $?$ & $?$ \\
\hline Spur/branch height ratio & 1 & $25 \%$ & - & $25 \%$ & & - & & $25 \%$ & - & $?$ & - \\
\hline
\end{tabular}

In both cases, monophyly of the genus was maximally supported, and S-DIVA indicated that Southeast Asia (Indomalayan region) is the ancestral region of Nebularmis, only slightly differing in the probability for an Oriental origin $\left(A_{1}=69 \%, B_{1}=65 \%\right)$. Node $A_{2}$ does not conclusively identify the ancestral region for the clade $((N$. reticulatus $((N$. cirinoi $(N$. burmensis $\mathbf{s p .}$ nov. $+N$. indicus sp. nov. $)))$, but the clade $((N$. cirinoi ( $N$. burmensis sp. nov. $+N$. indicus sp. nov.)) was inferred as having an Oriental origin in both trees $\left(A_{3}\right.$ and $\left.B_{3}=100 \%\right)$, thus implying the dispersal of $N$. cirinoi to the Afrotropics. Node $\mathrm{B}_{2}$ is analogously inconclusive regarding the ancestral region for the putative sister species $N$. reticulatus and $N$. auratus sp. nov.

\section{Discussion}

\section{Morphology of Nebularmis}

The original generic diagnosis of Nebularmis by Gąsiorek et al. [26] was based on populations of $N$. reticulatus and $N$. cirinoi examined at the time of its erection, supplied by the scarce and mostly dubious data from the original descriptions of other species known at the time. While studying the description of Claxtonia 

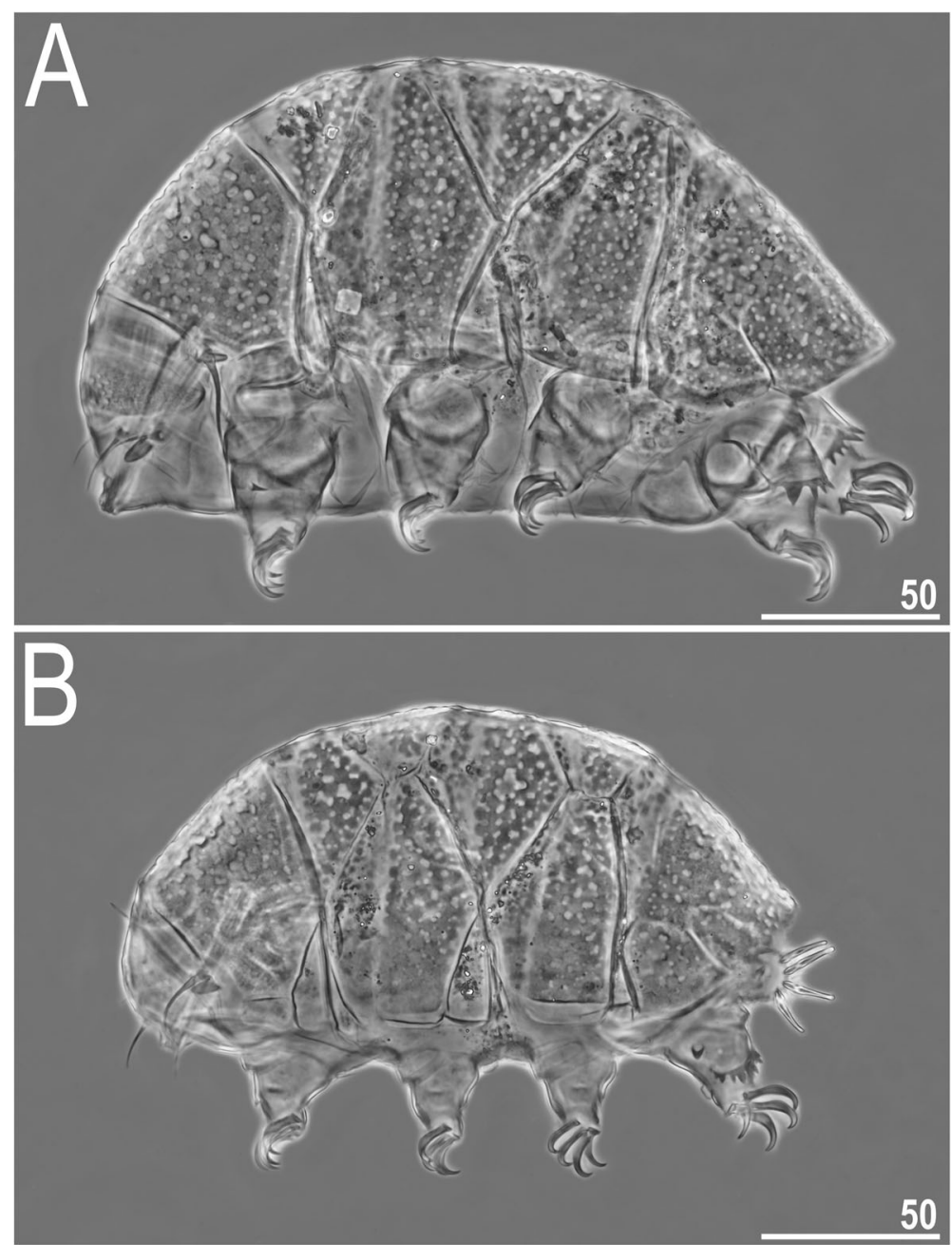

Fig. 12 Habitus of Nebularmis indicus sp. nov. (PCM): A - holotypic of in lateral view, B - allotypic $\hat{o}$ in dorsolateral view. Scale bars in $\mu m$

crebraclava [66], we noted that the species exhibits an intracuticular sponge layer and that the sculpture resembles that of $N$. bhutanensis sp. nov. Thus, we concluded that Echiniscus crebraclava was incorrectly transferred to Claxtonia by Gąsiorek et al. [26]; herein, we rectify this mistake by designating the species as Nebularmis crebraclava comb. nov. Although Sun et al. [66] treated the spaces between epicuticular granules as pores, these spaces are not pores; they are simply thinned portions of the cuticle. The original description of the species also states that cephalic papillae are particularly thick, but these structures have a size and shape typical of Nebularmis (e.g., compare Fig. 1a in Sun et al. [66] with Fig. $6 \mathrm{a}, 9 \mathrm{a}, 10,12 \mathrm{a}$ herein). The discovery of $N$. bhutanensis sp. nov. and $N$. indicus sp. nov. forces an amendment of the diagnosis of the genus, as new morphological criteria must be introduced to accommodate the expanded variability. Epicuticular granules can be connected by striae in Nebularmis ( $N$. crebraclava, $N$. bhutanensis sp. nov. and $N$. indicus sp. nov.), as in Stellariscus [67] (however, the intracuticular sponge layer separates both genera, as granules are always solid and composed of a uniform cuticular matrix in the latter genus), or granules can be widely spaced, circular and unconnected ( $N$. burmensis sp. nov.), calling to mind the bumps in Echiniscus palmai [68] (Fig. 18a, c-h). In fact, E. palmai shares some characteristics of Nebularmis: the intracuticular matrix is similar to the sponge layer (Fig. 18b), subcephalic plates are present (genital plates were not mentioned in the original description and are not discernible in the examined specimens due to retracted legs IV), and claws are long, firm and sabrelike. Moreover, dorsal bumps also tend to merge in the posterior portions of some plates (Fig. 18f). Based on these premises, we hypothesize that this species is related to Nebularmis or perhaps should be incorporated into this genus. The argument against its inclusion in Nebularmis involves the presence of weakly sclerotized 


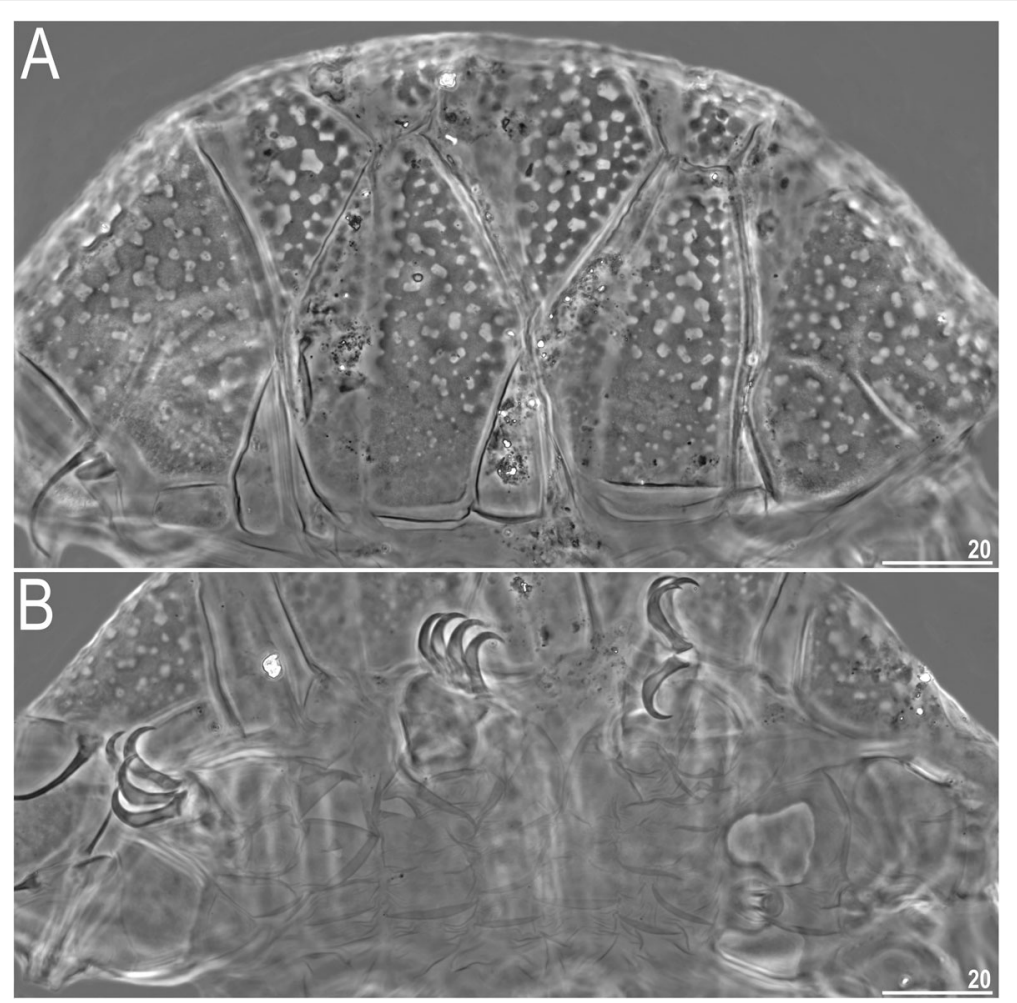

Fig. 13 Sculpturing of Nebularmis indicus sp. nov. (allotypic ô, PCM): A - dorsal view, B - ventral view (note regular wrinkling characteristic for the genus and male gonopore between smooth genital plates). Scale bars in $\mu \mathrm{m}$

stylet supports, but presently it is difficult to determine whether this taxonomic criterion is homogenous in every monophyletic echiniscid genus, especially within the Echiniscus line [34].

Stellariscus, with characteristic black pigmented eyes [67], is generally easily distinguishable from red-eyed Nebularmis when specimens are observed in vivo (Fig. 19). However, eye pigmentation can dissolve rapidly in the smallest individuals after mounting in Hoyer's medium. In addition to the abovementioned difference in dorsal sculpturing, the ventral cuticle is also divergent in both genera. In Nebularmis, wrinkling is regular and continuous, whereas the ventral plates of Stellariscus are autapomorphic, with two distinct types of which one type has nondistinctive outer margins when observed under LCM. Nevertheless, the morphological and reproductive similarities between Nebularmis and Stellariscus should be considered superficial, as the latter genus probably occupies a more basal position within the Echiniscus lineage [4]. The finding of males of two new Nebularmis species was unexpected, although not unheard of in the history of echiniscid taxonomy; for example, Echiniscus was once considered exclusively parthenogenetic [69]. In fact, despite being one of the first described tardigrade genera [31], Echiniscus males were detected only at the end of the XX century [69-72].

\section{Taxonomic key}

The key provided below is mostly based on qualitative traits of sexually mature (adult) individuals. This is a usual practice in modern echiniscid taxonomy, as previous authors did not distinguish between different life stages. Consequently, larvae and juveniles are excluded from the key since they are not known for every species. Furthermore, representatives of Nebularmis designated in $[26,28]$ as nomina dubia (i.e., N. carsicus, N. mihelcici, $N$. nobilis, $N$. tardus) or nomina inquirenda ( $N$. japonicus, N. markezi, N. phocae) or junior synonyms (N. mihelcici) were also excluded. Importantly, the generic affinity of $N$. markezi is uncertain since eye pigment in this species was described by Mihelčič [73] as blackred to black, whereas all Nebularmis specimens we examined before mounting in Hoyer's medium had red eyes, and no variability in this trait has been detected within any of the known echiniscid genera [34] (i.e., if present, eyes are either red or black). Thus, although the sculpture is similar to that of Nebularmis (see Fig. 20 for direct comparisons between scapular plates of Nebularmis spp.), we excluded this species from the key until this ambiguity is resolved.

1. Striae between epicuticular granules present ...................2

-. Striae between epicuticular granules absent .....................4

2(1). Pedal plates IV sculptured 

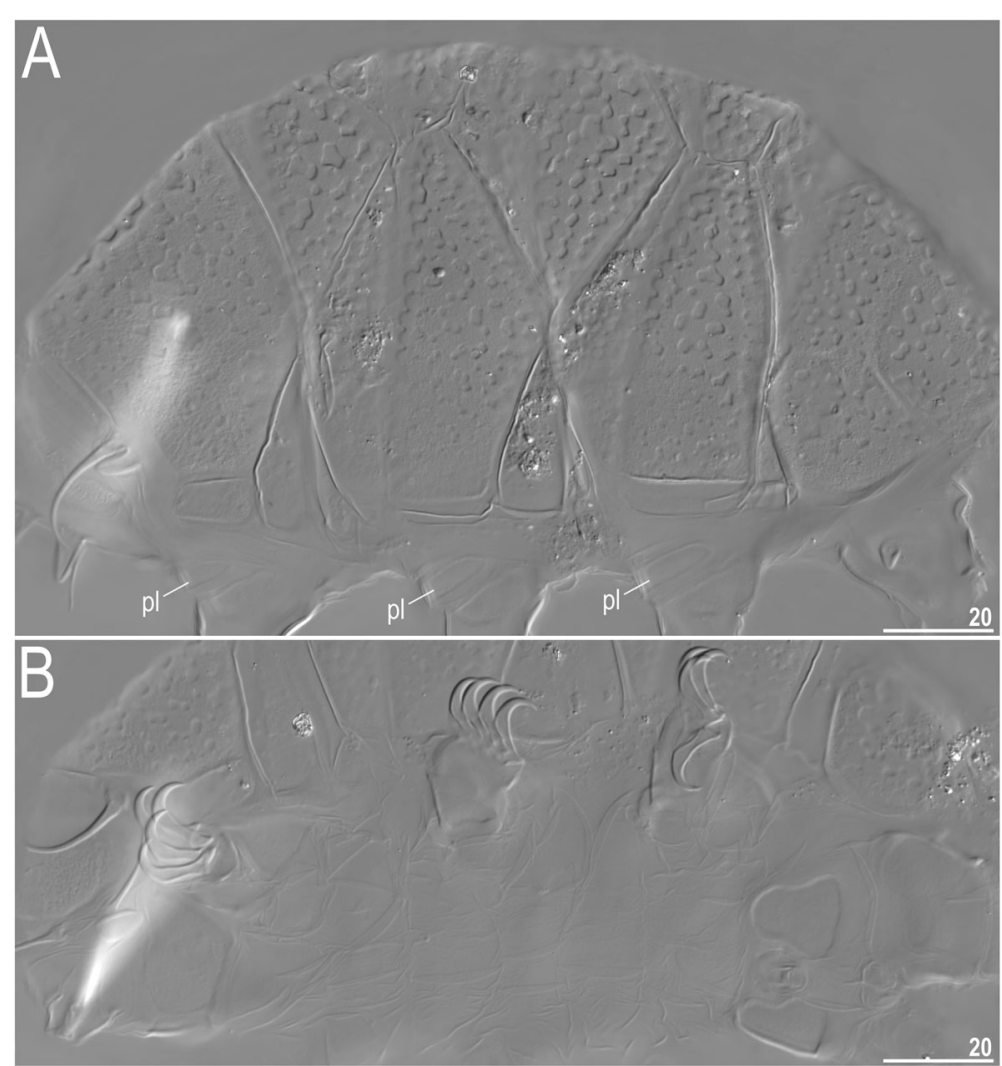

Fig. 14 Sculpturing of Nebularmis indicus sp. nov. (allotypic $\left.{ }^{\jmath}, \mathrm{NCM}\right)$ : A - dorsal view (pl - pulvini), B - ventral view. Scale bars in $\mu m$

-. Pedal plates IV unsculptured

Nebularmis indicus sp. nov.

3(2). Secondary clavae greatly enlarged, micropores present in the scapular plate

Nebularmis bhutanensis sp. nov.

-. Secondary clavae not enlarged, micropores absent in the scapular plate

Nebularmis crebraclava (Sun et al., 2014)
4(1). Claw spurs heteronych .. Nebularmis cirinoi (Binda \& Pilato, 1993)

-. Claw spurs isonych .. . .5

5(4). Claw spurs with blunt ends. Nebularmis auratus sp. nov.

-. Claw spurs with acute ends

6(5). Granules in the anterior portions of paired segmental plates in the shape of prominently convex bumps
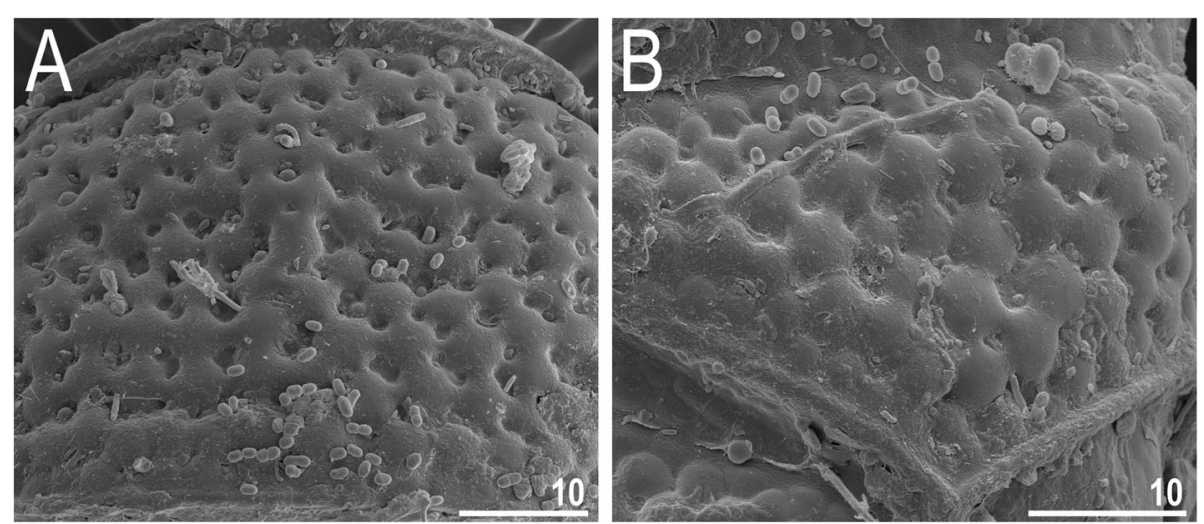

Fig. 15 Dorsal sculpturing of Nebularmis indicus sp. nov. (SEM): A - scapular plate, B - posterior portion of the paired segmental plate II. The anterior directed upwards. Scale bars in $\mu \mathrm{m}$ 

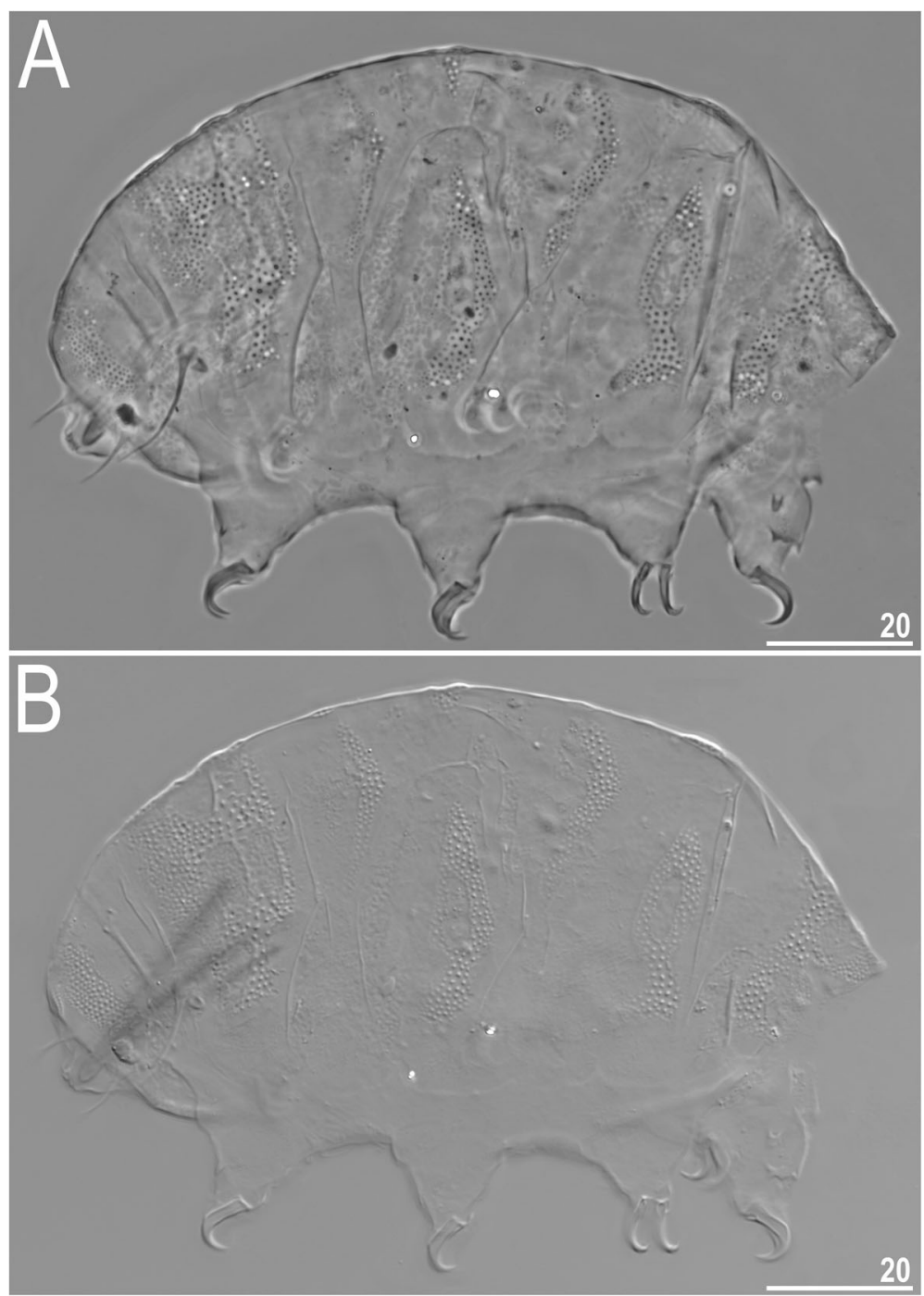

Fig. 16 Larval habitus of Nebularmis indicus sp. nov.: A - dorsolateral view (PCM), B - dorsolateral view (NCM). Scale bars in $\mu m$

that are clearly separated; cirri $A<20 \%$ of the body length ... Nebularmis burmensis sp. nov.

-. Granules in anterior portions of paired segmental plates flattened and often merged; cirri $A>25 \%$ of the body length

Nebularmis reticulatus (Murray, 1905)

\section{Biogeography of Nebularmis in the context of echiniscid phylogeny}

The oldest record of Nebularmis in Asia is that of Murray [74]. He reported Nebularmis reticulatus from the Sikkim Himalayas, and the presence of this typical Palearctic species in this region cannot be dismissed since it was reported from the neighboring Nepal [75] and later reaffirmed during the formal redescription and re-examination of those specimens [28]. Since the Indian subcontinent and Indochina are characterized by subtropical and tropical climates, in contrast to the typical mountainous or high boreal records of this species, it seems justified to hypothesize that the Himalayas most likely define the southernmost boundary of the N. reticulatus range. Specimens representing Nebularmis were found in Greenland [36], but the present condition of those slides does not allow confirmation of their affinity to $N$. reticulatus. Even if $N$. reticulatus was indeed recorded in Greenland, anthropogenic dispersal would seem to be the most likely explanation. Although Greenland is traditionally regarded as a part of the Nearctic, its invertebrate fauna is largely a mixture of Palearctic, cosmopolitan and endemic taxa [76, 77]; thus, the eventual presence of $N$. reticulatus in Greenland would not affect the status of a principally Palearctic species [28]. Nebularmis is certainly present in the Neotropical region [29,36], but the taxonomic identity of 
Table 8 Measurements [in $\mu \mathrm{m}$ ] of selected morphological structures of $N$. indicus sp. nov. (type series) mounted in Hoyer's medium. Abbreviations: sp - the proportion between the length of a given structure and the length of the scapular plate, ? unknown

\begin{tabular}{|c|c|c|c|c|c|c|c|c|c|c|c|c|}
\hline \multirow[t]{2}{*}{ CHARACTERISTIC } & \multicolumn{2}{|c|}{$\begin{array}{l}\text { Holotype } \\
(\text { ( ) }\end{array}$} & \multicolumn{2}{|l|}{ q } & \multicolumn{2}{|c|}{$\begin{array}{l}\text { Allotype } \\
\left(\delta^{\lambda}\right)\end{array}$} & \multicolumn{2}{|l|}{$\hat{0}$} & \multicolumn{2}{|c|}{ Juvenile } & \multicolumn{2}{|l|}{ Larva } \\
\hline & $\mu \mathrm{m}$ & $s p$ & $\mu \mathrm{m}$ & $s p$ & $\mu \mathrm{m}$ & $s p$ & $\mu \mathrm{m}$ & $s p$ & $\mu \mathrm{m}$ & $s p$ & $\mu \mathrm{m}$ & $s p$ \\
\hline Body length & 227 & 387 & 197 & 380 & 191 & 381 & 162 & 423 & 152 & 347 & 113 & 459 \\
\hline Scapular plate length & 58.7 & - & 51.8 & - & 50.1 & - & 38.3 & - & 43.8 & - & 24.6 & - \\
\hline \multicolumn{13}{|l|}{ Head appendage lengths } \\
\hline Cirrus internus & 17.6 & 30.0 & 14.6 & 28.2 & 15.9 & 31.7 & 13.5 & 35.2 & 11.0 & 25.1 & 6.6 & 26.8 \\
\hline Cephalic papilla & 9.1 & 15.5 & 7.1 & 13.7 & 8.5 & 17.0 & 7.4 & 19.3 & & & 3.7 & 15.0 \\
\hline Cirrus externus & 23.1 & 39.4 & 18.6 & 35.9 & 18.2 & 36.3 & 20.9 & 54.6 & 15.6 & 35.6 & 10.6 & 43.1 \\
\hline Clava & 7.1 & 12.1 & 6.8 & 13.1 & 6.7 & 13.4 & 7.1 & 18.5 & 5.9 & 13.5 & 4.4 & 17.9 \\
\hline Cirrus $A$ & 48.8 & 83.1 & 37.0 & 71.4 & 38.1 & 76.0 & 42.3 & 110.4 & 31.1 & 71.0 & 17.9 & 72.8 \\
\hline Cirrus A/body length ratio & $21 \%$ & - & $19 \%$ & - & $20 \%$ & - & $26 \%$ & - & $20 \%$ & - & $16 \%$ & - \\
\hline \multicolumn{13}{|l|}{ Body appendage lengths } \\
\hline Spine on leg I length & 5.2 & 8.9 & 3.5 & 6.8 & 3.5 & 7.0 & 3.9 & 10.2 & 3.4 & 7.8 & 1.8 & 7.3 \\
\hline Papilla on leg IV length & 5.4 & 9.2 & 4.6 & 8.9 & 5.4 & 10.8 & 4.4 & 11.5 & 3.2 & 7.3 & 2.3 & 9.3 \\
\hline Number of teeth on the collar & 8 & - & 5 & - & 6 & - & 7 & - & 6 & - & 3 & - \\
\hline \multicolumn{13}{|l|}{ Claw I heights } \\
\hline Branch & 16.1 & 27.4 & 14.5 & 28.0 & 13.0 & 25.9 & 12.4 & 32.4 & 11.1 & 25.3 & 8.0 & 32.5 \\
\hline Spur & 2.1 & 3.6 & $?$ & $?$ & 2.4 & 4.8 & 2.2 & 5.7 & 2.1 & 4.8 & 1.8 & 7.3 \\
\hline Spur/branch height ratio & $13 \%$ & - & $?$ & - & $18 \%$ & - & $18 \%$ & - & $19 \%$ & - & $23 \%$ & - \\
\hline \multicolumn{13}{|l|}{ Claw II heights } \\
\hline Branch & 14.2 & 24.2 & 12.6 & 24.3 & 12.5 & 25.0 & 11.7 & 30.5 & $?$ & $?$ & 7.3 & 29.7 \\
\hline Spur & 2.4 & 4.1 & $?$ & $?$ & 2.2 & 4.4 & 2.1 & 5.5 & $?$ & $?$ & 1.3 & 5.3 \\
\hline Spur/branch height ratio & $17 \%$ & - & $?$ & - & $18 \%$ & - & $18 \%$ & - & $?$ & - & $18 \%$ & - \\
\hline \multicolumn{13}{|l|}{ Claw III heights } \\
\hline Branch & 15.1 & 25.7 & 13.2 & 25.5 & 12.4 & 24.8 & 10.6 & 27.7 & 11.3 & 25.8 & 7.1 & 28.9 \\
\hline Spur & 2.3 & 3.9 & 1.9 & 3.7 & 1.8 & 3.6 & 1.8 & 4.7 & $?$ & $?$ & 1.6 & 6.5 \\
\hline Spur/branch height ratio & $15 \%$ & - & $14 \%$ & - & $15 \%$ & - & $17 \%$ & - & $?$ & - & $23 \%$ & - \\
\hline \multicolumn{13}{|l|}{ Claw IV heights } \\
\hline Branch & 18.0 & 30.7 & 16.4 & 31.7 & 15.8 & 31.5 & 15.6 & 40.7 & 11.7 & 26.7 & 8.1 & 32.9 \\
\hline Spur & 3.0 & 5.1 & $?$ & $?$ & $?$ & $?$ & $?$ & $?$ & 1.8 & 4.1 & 2.0 & 8.1 \\
\hline Spur/branch height ratio & $17 \%$ & - & $?$ & - & $?$ & - & $?$ & - & $15 \%$ & - & $25 \%$ & - \\
\hline
\end{tabular}

South American individuals remains obscure. Nebularmis phocae requires a redescription [28], and there is a chance of conspecificity with $N$. cirinoi [63] since we documented a wide distribution of this species in the African and Asian tropics and the species may be pantropical. The specimen from the Dastych collection originating from the Andes and representing Nebularmis, which we examined, is different from all other $\mathrm{Neb}$ ularmis spp. by its elongated and thin claws; thus, it most likely represents a new species.

Nebularmis specimens from the Ruwenzori Mountains (Central Africa) and Doi Inthanon (Chiang Mai,
Northern Thailand) are unidentifiable due to their poor states. The dorsal plate sculpturing of the African material clearly resembles $N$. cirinoi and these specimens likely belong to this taxon, as each location from which specimens were reported was in a mountainous tropical rainforest (this study, [78]). An undetermined species, most closely resembling $N$. cirinoi (misidentified as a Viridiscus in Tsaliki et al. [79]), inhabits the Hawaiian Archipelago. Consequently, Nebularmis, with records throughout the world, has a very wide geographic distribution, and although it has not been reported from the Nearctic 


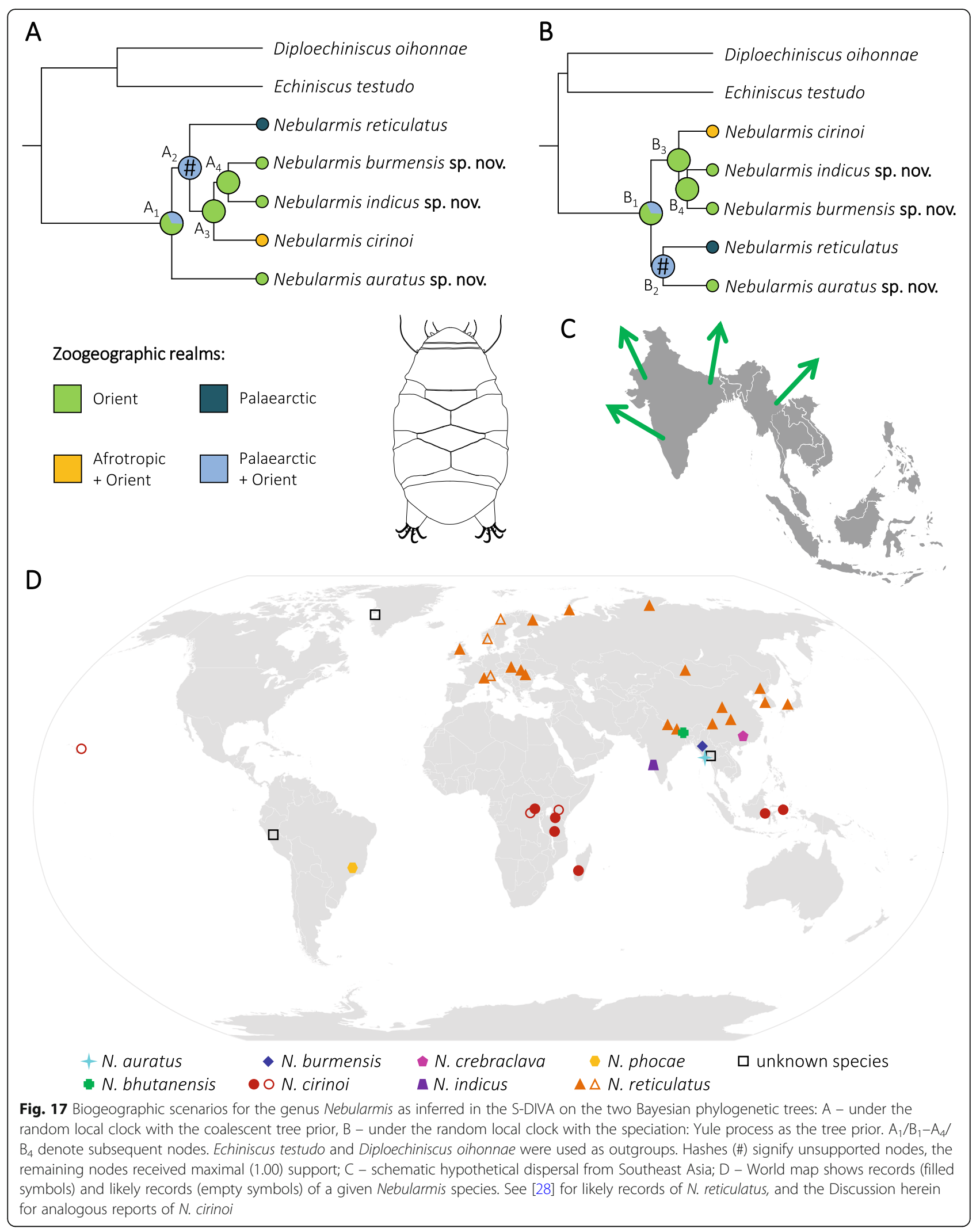


Table 9 Discriminative criteria used in Nebularmis taxonomy (all traits refer to states present in adults if not referred directly to other life stages; comparison based on all examined populations, see also [78, 28] for $N$. cirinoi and $N$ reticulatus)

\begin{tabular}{|c|c|c|c|c|c|c|c|}
\hline CHARACTERISTIC & $\begin{array}{l}\text { Nebularmis } \\
\text { auratus sp. } \\
\text { nov. }\end{array}$ & $\begin{array}{l}\text { Nebularmis } \\
\text { bhutanensis } \\
\text { sp. nov. }\end{array}$ & $\begin{array}{l}\text { Nebularmis } \\
\text { burmensis sp. } \\
\text { nov. }\end{array}$ & $\begin{array}{l}\text { Nebularmis } \\
\text { cirinoi }\end{array}$ & $\begin{array}{l}\text { Nebularmis } \\
\text { crebraclava }\end{array}$ & $\begin{array}{l}\text { Nebularmis indicus } \\
\text { sp. nov. }\end{array}$ & $\begin{array}{l}\text { Nebularmis } \\
\text { reticulatus }\end{array}$ \\
\hline Cephalic papilla & $\begin{array}{l}\text { elongated } \\
\text { and thin }\end{array}$ & $\begin{array}{l}\text { very large and } \\
\text { swollen }\end{array}$ & $\begin{array}{l}\text { elongated and } \\
\text { thin }\end{array}$ & $\begin{array}{l}\text { elongated and } \\
\text { thin }\end{array}$ & $\begin{array}{l}\text { elongated and } \\
\text { thin }\end{array}$ & elongated and thin & $\begin{array}{l}\text { elongated and } \\
\text { thin }\end{array}$ \\
\hline Primary clava & $\begin{array}{l}\text { elongated, } \\
\text { reduced }\end{array}$ & $\begin{array}{l}\text { blunt-ended, } \\
\text { of average size }\end{array}$ & $\begin{array}{l}\text { elongated, } \\
\text { reduced }\end{array}$ & $\begin{array}{l}\text { blunt-ended, of } \\
\text { average size }\end{array}$ & $\begin{array}{l}\text { blunt-ended, of } \\
\text { average size }\end{array}$ & elongated, reduced & $\begin{array}{l}\text { usually blunt- } \\
\text { ended, of average } \\
\text { size }\end{array}$ \\
\hline Cirrus $A$ & $\begin{array}{l}17-22 \% \text { of } \\
\text { the body } \\
\text { length, with } \\
\text { smooth and } \\
\text { thickened } \\
\text { proximal end } \\
\text { of flagellum }\end{array}$ & $\begin{array}{l}22-26 \% \text { of the } \\
\text { body length, } \\
\text { with smooth } \\
\text { and slightly } \\
\text { thickened } \\
\text { proximal end } \\
\text { of flagellum }\end{array}$ & $\begin{array}{l}16-19 \% \text { of the } \\
\text { body length, } \\
\text { with smooth } \\
\text { proximal end of } \\
\text { flagellum } \\
\text { roughly equal in } \\
\text { width to the } \\
\text { distal end }\end{array}$ & $\begin{array}{l}28-35 \% \text { of the } \\
\text { body length, } \\
\text { with smooth } \\
\text { and slightly } \\
\text { thickened } \\
\text { proximal end } \\
\text { of flagellum }\end{array}$ & $\begin{array}{l}16-27 \% \text { of the } \\
\text { body length, with } \\
\text { smooth and } \\
\text { slightly thickened } \\
\text { proximal end of } \\
\text { flagellum }\end{array}$ & $\begin{array}{l}19-26 \% \text { of the body } \\
\text { length, with smooth } \\
\text { and thickened } \\
\text { proximal end of } \\
\text { flagellum }\end{array}$ & $\begin{array}{l}27-63 \% \text { of the } \\
\text { body length, } \\
\text { often with rugose } \\
\text { proximal end of } \\
\text { flagellum roughly } \\
\text { equal in width to } \\
\text { the distal end }\end{array}$ \\
\hline $\begin{array}{l}\text { Micropores in the } \\
\text { scapular plate }\end{array}$ & $\begin{array}{l}\text { present and } \\
\text { randomly } \\
\text { distributed } \\
\text { (absent in } \\
\text { juveniles) }\end{array}$ & $\begin{array}{l}\text { present along } \\
\text { anterior and } \\
\text { posterior } \\
\text { margins }\end{array}$ & absent & absent & absent & absent & $\begin{array}{l}\text { absent or present } \\
\text { along anterior } \\
\text { and posterior } \\
\text { margins (present } \\
\text { in juveniles) }\end{array}$ \\
\hline $\begin{array}{l}\text { Epicuticular } \\
\text { granules }\end{array}$ & $\begin{array}{l}\text { tendency } \\
\text { towards } \\
\text { merging, but } \\
\text { still well- } \\
\text { separated in } \\
\text { some plates }\end{array}$ & $\begin{array}{l}\text { well-separated } \\
\text { in all plates, } \\
\text { hexagonal and } \\
\text { not circular, } \\
\text { with evident } \\
\text { striae }\end{array}$ & $\begin{array}{l}\text { well-separated in } \\
\text { median and } \\
\text { anterior portions } \\
\text { of paired } \\
\text { segmental plates, } \\
\text { evident bumps } \\
\text { in the latter }\end{array}$ & $\begin{array}{l}\text { strong } \\
\text { tendency } \\
\text { towards } \\
\text { merging, } \\
\text { circular and } \\
\text { very wide }\end{array}$ & $\begin{array}{l}\text { well-separated in } \\
\text { all plates, with } \\
\text { very wide spaces } \\
\text { between them, } \\
\text { hexagonal and } \\
\text { not circular, with } \\
\text { evident striae }\end{array}$ & $\begin{array}{l}\text { well-connected by } \\
\text { thick striae but } \\
\text { clearly separated in } \\
\text { all plate portions } \\
\text { except for the } \\
\text { lateralmost portions } \\
\text { of paired segmental } \\
\text { plates }\end{array}$ & $\begin{array}{l}\text { strong tendency } \\
\text { towards merging, } \\
\text { usually visible in } \\
\text { the scapular plate }\end{array}$ \\
\hline Pedal plate IV & unsculptured & $\begin{array}{l}\text { strongly } \\
\text { sculptured }\end{array}$ & unsculptured & $\begin{array}{l}\text { weakly } \\
\text { sculptured }\end{array}$ & $\begin{array}{l}\text { strongly } \\
\text { sculptured }\end{array}$ & unsculptured & unsculptured \\
\hline $\begin{array}{l}\text { Claw branches IV } \\
{[\mu \mathrm{m} / \mathrm{sp}]}\end{array}$ & $\begin{array}{l}19.2-22.2 \\
31.6-33.6\end{array}$ & $\begin{array}{l}17.3-20.1 \\
34.4-44.9\end{array}$ & $\begin{array}{l}18.1-20.5 \\
32.9-37.1\end{array}$ & $\begin{array}{l}15.2-19.7 \\
26.6-33.7\end{array}$ & $16.1-21.4^{b}$ & $\begin{array}{l}15.6-18.0 \\
30.7-40.7\end{array}$ & $\begin{array}{l}17.5-33.9 \\
29.9-49.4\end{array}$ \\
\hline Claw spurs & $\begin{array}{l}\text { of average } \\
\text { size, isonych } \\
\text { and with } \\
\text { blunt ends }\end{array}$ & $\begin{array}{l}\text { very large and } \\
\text { heteronych, } \\
\text { spurs IV larger } \\
\text { and more } \\
\text { divergent } \\
\text { from branches } \\
\text { than spurs I-III }\end{array}$ & $\begin{array}{l}\text { small and short, } \\
\text { isonych }\end{array}$ & $\begin{array}{l}\text { of average size } \\
\text { and } \\
\text { heteronych, } \\
\text { spurs IV larger } \\
\text { and more } \\
\text { divergent from } \\
\text { branches than } \\
\text { spurs I-III }\end{array}$ & $\begin{array}{l}\text { very large, no } \\
\text { data available on } \\
\text { whether spurs IV } \\
\text { differ from spurs } \\
\text { I-III }\end{array}$ & $\begin{array}{l}\text { small and short, } \\
\text { isonych }\end{array}$ & large and isonych \\
\hline Males $^{a}$ & unknown & present & unknown & absent & present & present & absent \\
\hline
\end{tabular}

\footnotetext{
${ }^{a}$ Numerous populations of $N$. cirinoi and $N$ reticulatus have been examined, and no males were found; thus, the assertion about their parthenogenetic nature is supported. For two other species, Nebularmis auratus sp. nov. and Nebularmis burmensis sp. nov., population sizes were too small to exclude dioecy ${ }^{b}$ Data not provided in the original description [66]

Proximal end of flagellum = flagellum base
}

and Australasia [32], we hypothesize that these gaps in its cosmopolitan distribution are most likely due to undersampling in these regions combined with the rarity of the genus.

Southeast Asia has an intricate geological history, with the Indian subcontinent and Indochina considered a part of the Gondwanan paleocontinent that later joined the Laurasian Palearctic region [80-82]. Nebularmis is inferred herein as having an Oriental ancestry, which potentially renders this region vital for echiniscid diversification. However, Southeast Asia belongs to one of the worst-sampled areas of the globe, which is evidenced, for example, by the fact that three out of the four new Nebularmis species described in this study are also the first tardigrade records for Bhutan and Myanmar. As many post-Gondwana taxa seem basal with respect to the derived Laurasian fauna, they are important in the understanding of heterotardigrade phylogeny [34, 83, 84]. In fact, the number of Laurasian echiniscid genera is much higher than that of Gondwanan genera, at 6:3 (Diploechiniscus, Proechiniscus, Multipseudechiniscus, Novechiniscus, Parechiniscus and Cornechiniscus, the last likely dispersed to Africa and South America, vs Antechiniscus, Mopsechiniscus and 

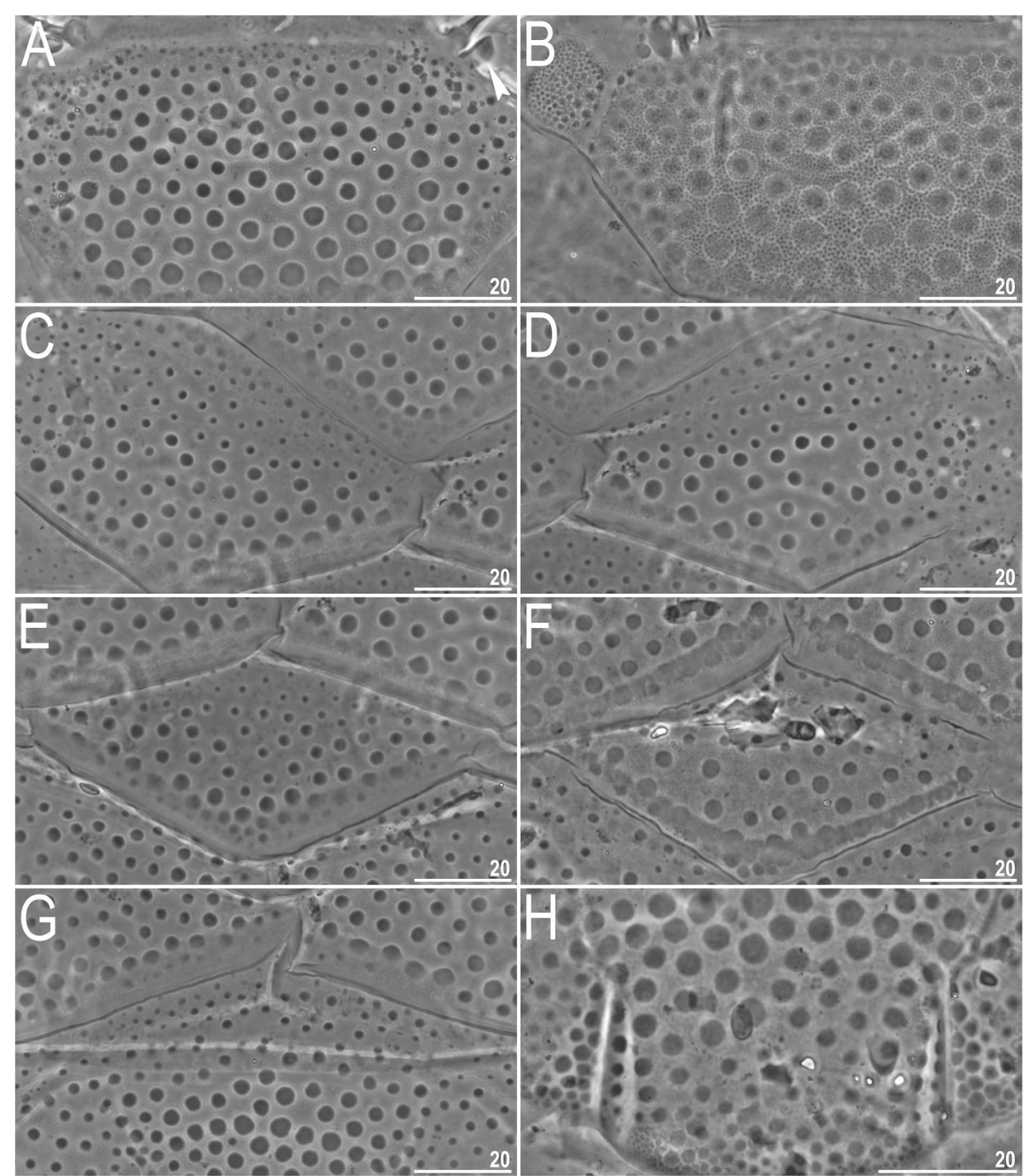

Fig. 18 Dorsal plate morphology of Echiniscus palmai (PCM): A - surface of the scapular plate (the incised arrowhead indicates the blunt-ended clava), B - inner sponge layer, C-D - paired segmental plates, E-F - second median plate, G - third median plate; $\mathrm{H}$ - caudal (terminal) plate with incisions. Scale bars in $\mu \mathrm{m}$

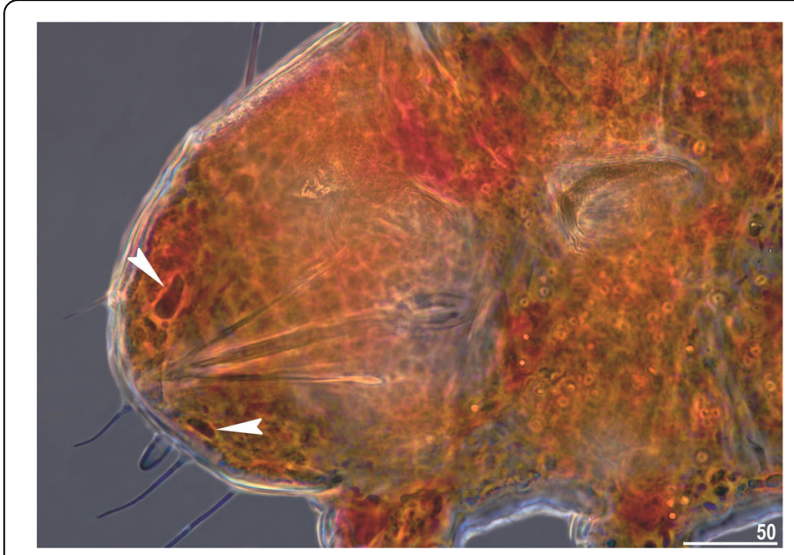

Fig. 19 A living specimen of Nebularmis reticulatus (population IT.126 from [28]) showing large red eyes. Scale bar in $\mu \mathrm{m}$
Barbaria, the last of which contains one species that dispersed to the southern Nearctic region [85]). As Southeast Asia is not as geologically old as South America and Australia, the presented hypothesis relating to the Oriental origin of Nebularmis involves its relatively recent divergence and radiation away from the current centers of relic Gondwanan tardigrade faunal diversity $[34,86]$.

\section{Spurious taxa}

Tardigrade taxonomy is burdened with the same problems as encountered in other meiofaunal groups that underwent preliminary study in the XVIII and XIX centuries, i.e.: a lack of type series, species descriptions considered by modern standards as insufficient and/or inadequate, difficulties with discerning intraspecific from interspecific variability, and lack of type DNA sequences 

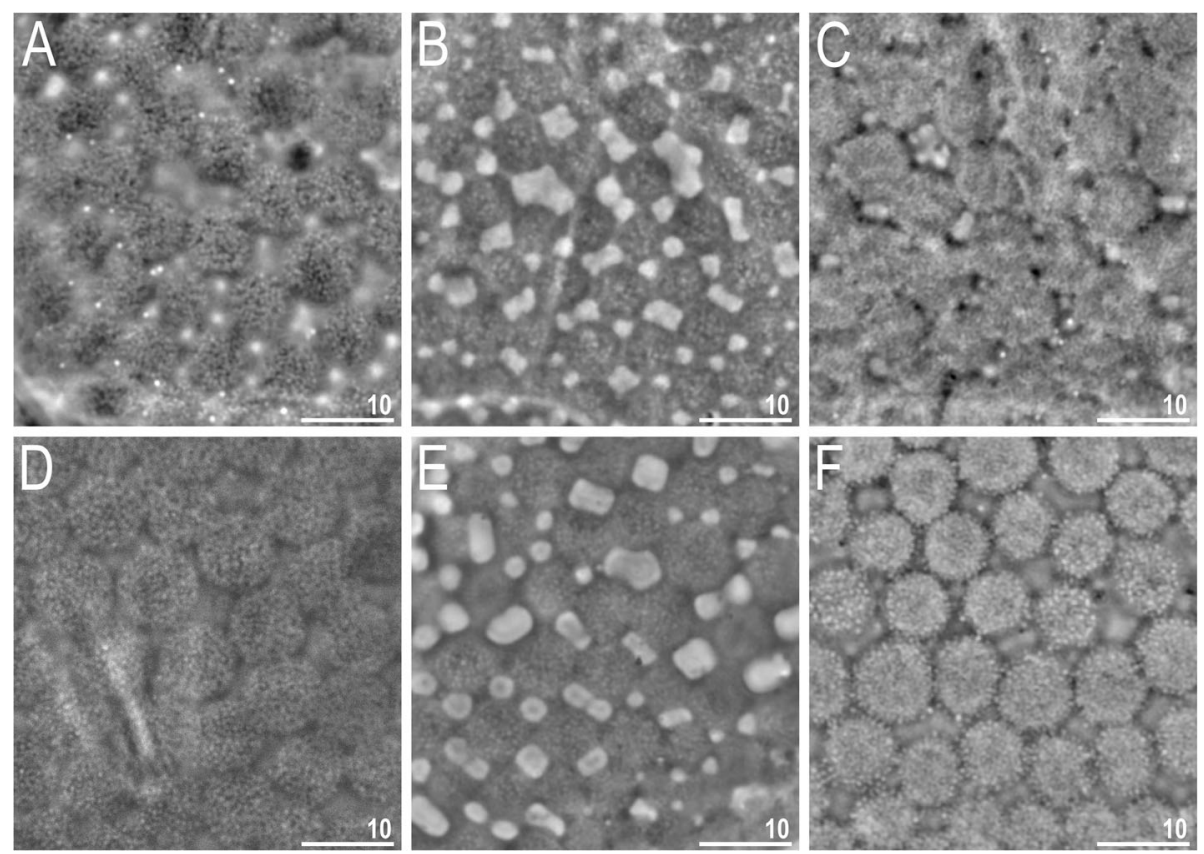

Fig. 20 Interspecific variability in scapular plate sculpturing in Nebularmis (PCM): A - N. auratus sp. nov., B - N. bhutanensis sp. nov., C - N. burmensis sp. nov., D - N. cirinoi, E - N. indicus sp. nov., F - N. reticulatus. Scale bars in $\mu m$

$[4,7-10,28,87]$. The state-of-the-art in phyla characterized by a much younger taxonomic history, such as Loricifera [88], is enviable compared to that in tardigrades. The first described representatives of these groups were analyzed in much greater detail, which allowed for a high resolution of detection of species diversity and reliable subsequent records of early-described species [89]. At the $13^{\text {th }}$ Symposium on Tardigrada in Modena, mirroring the actions of rotiferologists [35], a proposal to form a list of available names for this phylum in accordance with the rules of ICZN was put forward. There is a compelling need for the creation of such a list, as even a quick glance at the current checklist of tardigrade taxa, with a number of nomina inquirenda and species dubia embedded therein [22], reveals that significant problems exist with the reliability of species descriptions in numerous genera. Nebularmis can serve as a perfect example; of the eight valid species listed in the last edition of the checklist, no taxonomic obscurities were identified in only two species. The remaining six species are indistinguishable $[26,28]$; thus, the most practical thing to do would be to abandon using these names once and for all. Therefore, we urge the international community of tardigradologists to intensify actions leading to the uncluttering and sorting of tardigrade taxonomy. This will prevent nontaxonomists unacquainted with the meanders of systematics from using dubious names, e.g., in local checklists or ecological and experimental studies.

\section{Conclusions}

Nebularmis represents yet another echiniscid genus in which dorsal sculpturing and claw morphology are crucial taxonomic criteria [4, 26, 28, 34, 90-93]. Despite some similarities between Nebularmis with Stellariscus, the two genera are not directly related. Continental Asia is an important but mostly undersampled region in the context of echiniscid diversity and phylogeny. Finally, we propose enhancing efforts to eliminate dubious and/or unidentifiable water bear species from the modern professional literature by creating a list of available names.

\section{Supplementary Information}

The online version contains supplementary material available at https://doi. org/10.1186/s40851-021-00172-0.

Additional file 1. Primers and DNA amplification protocols.

Additional file 2. 185 rRNA alignment.

Additional file 3. $28 \mathrm{~S}$ rRNA alignment.

Additional file 4. ITS-1 alignment.

Additional file 5. ITS-2 alignment.

Additional file 6. $\mathrm{COl}$ alignment.

Additional file 7. Concatenated $18 \mathrm{~S}+28 \mathrm{~S}+$ ITS alignment used for the biogeography reconstructions.

\section{Acknowledgments}

Three anonymous reviewers and the Associate Editor, Dr. Hiroshi Kajihara, significantly improved our manuscript with their suggestions. Cristina Cruz, Jorge Domingos, Henrik Enghoff, Dominika Wilkosz and Artur Oczkowski are 
gratefully acknowledged for sampling in Asia. PG thanks Hieronymus Dastych (University of Hamburg) for discussions relating to Nebularmis reticulatus and for the loan of comparative material, and Reinhardt $M$. Kristensen (University of Copenhagen) for making the Danish collection of tardigrades available for examination. Diane Nelson (East Tennessee State University) generously donated her collection of New Zealand tardigrades, including specimens of Echiniscus palmai, to Jagiellonian University. Brian Blagden kindly proofread the manuscript and corrected the English. Alejandro López-López (Jagiellonian University) is acknowledged for discussions and advice.

\section{Authors' contributions}

PG conceptualized the work, sourced financial support, collected the data, analyzed the data, and wrote the manuscript; KV, JC, MV and PF collected and interpreted the data, and $Ł M$ conceptualized the work, interpreted the data and sourced financial support. All authors participated in writing the manuscript, read the final version of the manuscript and approved its submission for review.

\section{Funding}

The study was supported by the Polish National Science Centre via the 'Preludium' (grant no. 2019/33/N/NZ8/02777 to PG, supervised by $Ł M$ ) and 'Sonata Bis' programmes (grant no. 2016/22/E/NZ8/00417 to ŁM). Sampling was partially supported by the Polish Ministry of Science and Higher Education via the Diamond Grant (grant no. DI2015 014945 to PG, supervised by $Ł$ M). PG is a recipient of the 'Etiuda' (2020/36/T/NZ8/00360, funded by the National Science Centre) and 'Start' stipends (START 28.2020, funded by the Foundation for Polish Science). The research of PF was partially funded by Fundação para a Ciência e Tecnologia (FCT) through the strategic project UID/MAR/04292/2019 granted to MARE. Open-access publication of this article was funded by the BioS Priority Research Area under the program "Excellence Initiative - Research University" at Jagiellonian University in Kraków, Poland.

\section{Availability of data and materials}

All data generated or analyzed during this study are included in the article, with supplementary information files providing detailed phylogenetic datasets. Genetic data are deposited in GenBank.

\section{Declarations}

\section{Ethics approval and consent to participate}

Not applicable.

\section{Consent for publication}

Not applicable.

\section{Competing interests}

The authors declare that they have no competing interests.

\section{Author details}

${ }^{1}$ Department of Invertebrate Evolution, Institute of Zoology and Biomedical Research, Faculty of Biology, Jagiellonian University, Gronostajowa 9, 30-387 Kraków, Poland. ${ }^{2}$ Department of Biology, Faculty of Sciences, University of Porto, Rua Campo Alegre s/n, FC4, 4169-007 Porto, Portugal. ${ }^{3}$ MARE, Marine and Environmental Sciences Centre, ISPA - Instituto Universitário, Rua Jardim do Tabaco, 34, 1149-041 Lisbon, Portugal.

\section{Received: 7 October 2020 Accepted: 5 January 2021}

\section{Published online: 12 April 2021}

\section{References}

1. Faurby S, Jørgensen A, Kristensen RM, Funch P. Distribution and speciation in marine intertidal tardigrades: testing the roles of climatic and geographical isolation. J Biogeogr. 2012;39:1596-607.

2. Santos E, Veiga P, Rubal M, Bartels PJ, da Rocha CMC, Fontoura P. Batillipes pennaki Marcus, 1946 (Arthrotardigrada: Batillipedidae): deciphering a species complex. Zootaxa. 2019;4648:549-67.

3. Cesari M, Montanari M, Kristensen RM, Bertolani R, Guidetti R, Rebecchi L. An integrated study of the biodiversity within the Pseudechiniscus suillus- facettalis group (Heterotardigrada: Echiniscidae). Zool J Linn Soc. 2020;188: 717-32.

4. Gąsiorek P, Oczkowski A, Blagden B, Kristensen RM, Bartels PJ, Nelson DR, Suzuki AC, Michalczyk Ł. New Asian and Nearctic Hypechiniscus species (Heterotardigrada: Echiniscidae) signalize a pseudocryptic horn of plenty. Zool J Linn Soc. 2021. https://doi.org/10.1093/zoolinnean/zlaa110.

5. Morek W, Michalczyk $Ł$. First extensive multilocus phylogeny of the genus Milnesium (Tardigrada) reveals no congruence between genetic markers and morphological traits. Zool J Linn Soc. 2020;188:681-93.

6. Stec D, Vecchi M, Calhim S, Michalczyk $Ł$. New multilocus phylogeny reorganises the family Macrobiotidae (Eutardigrada) and unveils complex morphological evolution of the Macrobiotus hufelandi group. Mol Phyl Evol. 2021. https://doi.org/10.1016/j.ympev.2020.106987.

7. Stec D, Morek W, Gąsiorek P, Michalczyk Ł. Unmasking hidden species diversity within the Ramazzottius oberhaeuseri complex, with an integrative redescription of the nominal species for the family Ramazzottiidae (Tardigrada: Eutardigrada: Parachela). Syst Biodivers. 2018;16:357-76.

8. Stec D, Krzywański $Ł$, Arakawa K, Michalczyk $Ł$. A new redescription of Richtersius coronifer, supported by transcriptome, provides resources for describing concealed species diversity within the monotypic genus Richtersius (Eutardigrada). Zool Lett. 2020;6:2

9. Stec D, Krzywański $Ł$, Zawierucha K, Michalczyk $Ł$. Untangling systematics of the Paramacrobiotus areolatus species complex by an integrative redescription of the nominal species for the group, with multilocus phylogeny and species delineation in the genus Paramacrobiotus. Zool J Linn Soc. 2020;188:694-716.

10. Guidetti R, Cesari M, Bertolani R, Altiero T, Rebecchi L. High diversity in species, reproductive modes and distribution within the Paramacrobiotus richtersi complex (Eutardigrada, Macrobiotidae). Zool Lett. 2019;5:1.

11. Gąsiorek P, Michalczyk $Ł$. Phylogeny of Itaquasconinae in the light of the evolution of the flexible pharyngeal tube in Tardigrada. Zool Scr. 2020;49:499-515.

12. Jørgensen A, Kristensen RM, Møbjerg N. Phylogeny and integrative taxonomy of Tardigrada. In: Schill RO, editor. Water bears: the biology of tardigrades. Zoological Monographs; 2018. p. 95-114.

13. Kristensen RM, Hallas TE. The tidal genus Echiniscoides and its variability, with erection of Echiniscoididae fam.n. (Tardigrada). Zool Scr. 1980;9:113-27.

14. Bertolani R, Rebecchi L. A revision of the Macrobiotus hufelandi group (Tardigrada, Macrobiotidae), with some observations on the taxonomic characters of eutardigrades. Zool Scr. 1993;22:127-52.

15. Goldstein B. The emergence of the tardigrade Hypsibius exemplaris as a model system. CSH Protocols. 2018;11:859-66.

16. Gross V, Treffkorn S, Reichelt J, Epple L, Lüter C, Mayer G. Miniaturization of tardigrades (water bears): Morphological and genomic perspectives. Arthr Struct Dev. 2019;48:12-9.

17. Richaud M, Le Goff E, Cazevielle C, Ono F, Mori Y, Saini NL, Cuq P, Baghdiguian S, Godefroy N, Galas S. Ultrastructural analysis of the dehydrated tardigrade Hypsibius exemplaris unveils an anhydrobiotic-specific architecture. Sci Rep. 2020;10:4324.

18. Guidetti R, Bertolani R. Tardigrade taxonomy: an updated check list of the taxa and a list of characters for their identification. Zootaxa. 2005;845:1-46.

19. Degma P, Guidetti R. Notes to the current checklist of Tardigrada. Zootaxa. 2007;1579:41-53.

20. Bartels PJ, Apodaca JJ, Mora C, Nelson DR. A global biodiversity estimate of a poorly known taxon: phylum Tardigrada. Zool J Linn Soc. 2016;178:730-6.

21. Fontoura P, Bartels PJ, Jørgensen A, Kristensen RM, Hansen JG. A dichotomous key to the genera of the marine heterotardigrades (Tardigrada). Zootaxa. 2017;4294:1-45.

22. Degma P, Bertolani R, Guidetti R. Actual checklist of Tardigrada species (2009-2020, 38th edition); 2020. https://doi.org/10.25431/11380_1178608.

23. Degma P, Guidetti R. Tardigrade taxa. In: Schill RO, editor. Water bears: the biology of tardigrades. Zoological Monographs; 2018. p. 371-409.

24. Guil N, Jørgensen A, Giribet G, Kristensen RM. Congruence between molecular phylogeny and cuticular design in Echiniscoidea (Tardigrada, Heterotardigrada). Zool J Linn Soc. 2013;169:713-36.

25. Vicente F, Fontoura P, Cesari M, Rebecchi L, Guidetti R, Serrano A, Bertolani $R$. Integrative taxonomy allows the identification of synonymous species and the erection of a new genus of Echiniscidae (Tardigrada, Heterotardigrada). Zootaxa. 2013;3613:557-72.

26. Gąsiorek P, Morek W, Stec D, Michalczyk Ł. Untangling the Echiniscus Gordian knot: paraphyly of the "arctomys group" (Heterotardigrada: Echiniscidae). Cladistics. 2019;35:633-53. 
27. Murray J. The Tardigrada of the Scottish Lochs. Trans Roy Soc Edinburgh. 1905:41:677-98.

28. Gąsiorek P, Blagden B, Michalczyk $Ł$. Towards a better understanding of echiniscid intraspecific variability: A redescription of Nebularmis reticulatus (Murray, 1905) (Heterotardigrada: Echiniscoidea). Zool Anz. 2019;283:242-55.

29. du Bois-Reymond Marcus E. Sobre tardígrados brasileiros. Comun Zool Mus Hist Nat Montevideo. 1944;1:1-19.

30. Roberts A, Austin W, Evans K, Bird C, Schweizer M, Darling K. A new integrated approach to taxonomy: The fusion of molecular and morphological systematics with type material in benthic Foraminifera. PLoS One. 2016;11:e0158754.

31. Ramazzotti G, Maucci W. A history of tardigrade taxonomy. In: Nelson DR, editor. Proceedings of the Third International Symposium on the Tardigrada; 1982. p. 11-30.

32. Mclnnes SJ. Zoogeographic distribution of terrestrial/freshwater tardigrades from current literature. J Nat Hist. 1994;28:257-352.

33. Myers N, Mittermeier RA, Mittermeier CG, da Fonseca GAB, Kent J. Biodiversity hotspots for conservation priorities. Nature. 2000;403:853-8.

34. Kristensen RM. Generic revision of the Echiniscidae (Heterotardigrada), with a discussion of the origin of the family. In: Bertolani R, editor. Biology of tardigrades. Selected Symposia and Monographs U.Z.I.; 1987. p. 261-335.

35. Segers H, De Smet WH, Fischer C, Fontaneto D, Michaloudi E, Wallace RL, Jersabek CD. Towards a List of Available Names in Zoology, partim Phylum Rotifera. Zootaxa. 2012;3179:61-8.

36. Dastych H. The Tardigrada of Poland. Monogr Faun Pol. 1988;16:1-255.

37. Møbjerg N, Jørgensen A, Kristensen RM, Neves RC. Morphology and functional anatomy. In: Schill RO, editor. Water bears: the biology of tardigrades. Zoological Monographs; 2018. p. 57-94.

38. Dastych H. A new species of the genus Mopsechiniscus Du Bois-Reymond Marcus, 1944 (Tardigrada) from the Venezuelan Andes. Acta Biol Benrod. 1999;10:91-101.

39. Michalczyk $Ł$, Kaczmarek $Ł$. The Tardigrada Register: a comprehensive online data repository for tardigrade taxonomy. J Limnol. 2013;72:175-81.

40. Casquet JT, Thebaud C, Gillespie RG. Chelex without boiling, a rapid and easy technique to obtain stable amplifiable DNA from small amounts of ethanol-stored spiders. Mol Ecol Res. 2012;12:136-41.

41. Stec D, Kristensen RM, Michalczyk $Ł$. An integrative description of Minibiotus ioculator sp. nov. from the Republic of South Africa with notes on Minibiotus pentannulatus Londoño et al., 2017 (Tardigrada: Macrobiotidae). Zool Anz. 2020;286:117-34

42. Pleijel F, Jondelius U, Norlinder E, Nygren A, Oxelman B, Schander C, Sundberg P, Thollesson M. Phylogenies without roots? A plea for the use of vouchers in molecular phylogenetic studies. Mol Phyl Evol. 2008;48:369-71.

43. Doyère M. Mémoire sur les tardigrades. Ann Sci Nat Zool Paris Ser 2. 1840; 14:269-362

44. Richters F. Nordische Tardigraden. Zool Anz. 1903;27:168-72.

45. Katoh K, Misawa K, Kuma K, Miyata T. MAFFT: a novel method for rapid multiple sequence alignment based on fast Fourier transform. Nucleic Acids Res. 2002;30:3059-66.

46. Katoh $\mathrm{K}$, Toh H. Recent developments in the MAFFT multiple sequence alignment program. Brief Bioinform. 2008;9:286-98.

47. Hall TA. BIOEDIT: a user-friendly biological sequence alignment editor and analysis program for Windows 95/98/NT. Nucleic Acids Symp Ser. 1997;41: 95-8.

48. Thompson JD, Higgins DG, Gibson TJ. CLUSTAL W: improving the sensitivity of progressive multiple sequence alignment through sequence weighting, position-specific gap penalties and weight matrix choice. Nucleic Acids Res. 1994;22:4673-80.

49. Kumar S, Stecher G, Tamura K. MEGA7: Molecular Evolutionary Genetics Analysis version 7.0 for bigger datasets. Mol Biol Evol. 2016;33:1870-4.

50. Vaidya G, Lohman DJ, Meier R. SequenceMatrix: concatenation software for the fast assembly of multi-gene datasets with character set and codon information. Cladistics. 2011;27:171-80.

51. Lanfear R, Frandsen PB, Wright AM, Senfeld T, Calcott B. PartitionFinder 2: new methods for selecting partitioned models of evolution for molecular and morphological phylogenetic analyses. Mol Biol Evol. 2016;34:772-3.

52. Lanfear R, Calcott B, Ho SY, Guindon S. PartitionFinder: combined selection of partitioning schemes and substitution models for phylogenetic analyses. Mol Biol Evol. 2012;29:1695-701.

53. Drummond AJ, Rambaut A. BEAST: Bayesian evolutionary analysis by sampling trees. BMC Evol Biol. 2007;7:214.
54. Drummond AJ, Suchard MA. Bayesian random local clocks, or one rate to rule them all. BMC Biol. 2010;8:114.

55. Ferreira MAR, Suchard MA. Bayesian analysis of elapsed times in continuoustime Markov chains. Can J Stat. 2008;36:355-68.

56. Rambaut A, Suchard MA, Xie D, Drummond AJ. Tracer v1.6. 2014. Available from https://beast.bio.ed.ac.uk/Tracer

57. Ronquist F. Dispersal-vicariance analysis: A new approach to the quantification of historical biogeography. Syst Biol. 1997;46:195-203.

58. Yu Y, Harris AJ, Blair C, He XJ. RASP (Reconstruct Ancestral State in Phylogenies): a tool for historical biogeography. Mol Phyl Evol. 2015;87:46-9.

59. Yu Y, Blair C, He XJ. RASP 4: Ancestral state reconstruction tool for multiple genes and characters. Mol Biol Evol. 2020;37:604-6.

60. Marcus E. Zur Anatomie und Ökologie mariner Tardigraden. Zool Jahrb Abt Syst. 1927;53:487-558.

61. Richters F. Tardigrada. In: Kükenthal W, Krumbach T, editors. Handbuch der Zoologie. Vol. 3. Walter de Gruyter \& Co.; 1926. p. 58-61.

62. Thulin G. Über die Phylogenie und das System der Tardigraden. Hereditas. 1928;11:207-66.

63. Binda MG, Pilato G. Ridescrizione di Echiniscus reticulatus Murray, 1905 e descrizione di Echiniscus cirinoi, nuova specie di tardigrado della Tanzania. Animalia. 1993;20:55-8.

64. Fontaneto D. Molecular phylogenies as a tool to understand diversity in rotifers. Int Rev Hydrobiol. 2014;99:178-87.

65. Morek W, Stec D, Gąsiorek P, Surmacz B, Michalczyk Ł. Milnesium tardigradum Doyère, 1840: The first integrative study of interpopulation variability in a tardigrade species. J Zool Syst Evol Res. 2019;57:1-23.

66. Sun X, Li X, Feng W. Two new species of Tardigrada (Echiniscidae, Hypsibiidae) from China. Proc Biol Soc Wash. 2014;126:323-8.

67. Gąsiorek P, Suzuki AC, Kristensen RM, Lachowska-Cierlik D, Michalczyk $Ł$. Untangling the Echiniscus Gordian knot: Stellariscus gen. nov. (Heterotardigrada : Echiniscidae) from Far East Asia. Invertebr Syst. 2018;32: 1234-47.

68. Dastych H. A new species of the genus Echiniscus (Tardigrada) from New Zealand. Entomol Mitt Zool Mus Hamburg. 1997;12:209-15.

69. Dastych $\mathrm{H}$. Two new species of Tardigrada from the Canadian Subarctic with some notes on sexual dimorphism in the family Echiniscidae. Entomol Mitt Zool Staatsinst Zool Mus Hamburg. 1987;8:319-34.

70. Dastych H, Kristensen RM. Echiniscus ehrenbergi sp. n., a new water bear from the Himalayas. Entomol Mitt Zool Mus Hamburg. 1995;11:221-30.

71. Claxton SK. Sexual dimorphism in Australian Echiniscus (Tardigrada, Echiniscidae) with descriptions of three new species. Zool J Linn Soc. 1996; 116:13-33.

72. Miller WR, Claxton SK, Heatwole HF. Tardigrades of the Australian Antarctic Territories: Males in the genus Echiniscus (Tardigrada: Heterotardigrada). Zool Anz. 1999;238:303-9.

73. Mihelčič F. Ein weiterer Beitrag zur Kenntnis der Tardigraden Argentiniens. Verh Zool-Bot Ges Wien. 1971-2;110/111:47-52.

74. Murray J. Some Tardigrada of the Sikkim Himalaya. J Roy Microsc Soc. 1907; 27:269-73.

75. Dastych H. Some Tardigrada from the Himalayas (Nepal) with a description of Echiniscus (E.) nepalensis n. sp. Mem Ist Ital Idrobiol. 1975;32(Suppl):61-8.

76. Bergersen R. Is Greenland a zoogeographical unit of its own? J Biogeogr. 1995;22:1-6.

77. Sadler JP. Is Greenland a zoogeographic unit?' A response to Bergersen. J Biogeogr. 1998;25:399-403.

78. Gąsiorek P, Kristensen RM. Echiniscidae (Heterotardigrada) of Tanzania and Uganda. Trop Zool. 2018:31:131-60.

79. Tsaliki M, Meyer HA, Akobi NO, Hinton JG. A new species of the Echiniscus viridis group from the Hawaiian Islands. In: Book of Abstracts of the $14^{\text {th }}$ International Symposium on Tardigrada; 2018. p. 101.

80. Ridd MF. South-East Asia as a part of Gondwanaland. Nature. 1971;234:5313.

81. Metcalfe I. Palaeozoic and Mesozoic geological evolution of the SE Asian region: multidisciplinary constraints and implications for biogeography. In: Hall R, Holloway JD, editors. Biogeography and geological evolution of SE Asia. Backhuys Publishers; 1998. p. 25-41.

82. Usuki T, Lan C-Y, Wang K-L, Chiu H-Y. Linking the Indochina block and Gondwana during the Early Paleozoic: Evidence from U-Pb ages and $\mathrm{Hf}$ isotopes of detrital zircons. Tectonophysics. 2013;586:145-59.

83. McInnes SJ, Pugh PJA. An attempt to revisit the global biogeography of limno-terrestrial Tardigrada. J Limnol. 2007;66(Suppl. 1):90-6. 
84. Guidetti R, McInnes SJ, Cesari M, Rebecchi L, Rota-Stabelli O. Evolutionary scenarios for the origin of an Antarctic tardigrade species based on molecular clock analyses and biogeographic data. Contrib Zool. 2017;86:97-110.

85. Meyer HA, Tsaliki M, Sorgee B. New water bear records (Phylum Tardigrada) from South Carolina, southeastern USA, with the description of Echiniscus danieli sp. nov. (Heterotardigrada, Echiniscidae, bigranulatus group). Proc Biol Soc Wash. 2017;130:98-107.

86. Claxton SK. The taxonomy and distribution of Australian terrestrial tardigrades. PhD. thesis, Macquarie University, Sydney, Australia; 2004.

87. Fontoura P, Morais P. Assessment of traditional and geometric morphometrics for discriminating cryptic species of the Pseudechiniscus suillus complex (Tardigrada, Echiniscidae). J Zool Syst Evol Res. 2011; 49(Suppl. 1):26-33.

88. Kristensen RM. Loricifera, a new phylum with Aschelminthes characters from the meiobenthos. J Zool Syst Evol Res. 1983;21:163-80

89. Neves RC, Reichert H, Sørensen MV, Kristensen RM. Systematics of phylum Loricifera: Identification keys of families, genera and species. Zool Anz. 2016; 265:141-70

90. Pilato G, Lisi O. Echiniscus walteri, new species of tardigrade from Madagascar. Boll Mus Civ Stor Nat Verona. 2003;27:65-70.

91. Michalczyk $Ł$, Kaczmarek $Ł$. Revision of the Echiniscus bigranulatus group with a description of a new species Echiniscus madonnae (Tardigrada: Heterotardigrada: Echiniscidae) from South America. Zootaxa. 2006;1154:126.

92. Pilato $\mathrm{G}$, Fontoura $\mathrm{P}$, Lisi O. Remarks on the Echiniscus viridis group, with the description of a new species (Tardigrada, Echiniscidae). J Limnol. 2007; 66(Suppl. 1):33-9.

93. Tumanov DV. Analysis of non-morphometric morphological characters used in the taxonomy of the genus Pseudechiniscus (Tardigrada: Echiniscidae). Zool J Linn Soc. 2020;188:753-75.

\section{Publisher's Note}

Springer Nature remains neutral with regard to jurisdictional claims in published maps and institutional affiliations.

Ready to submit your research? Choose BMC and benefit from:

- fast, convenient online submission

- thorough peer review by experienced researchers in your field

- rapid publication on acceptance

- support for research data, including large and complex data types

- gold Open Access which fosters wider collaboration and increased citations

- maximum visibility for your research: over $100 \mathrm{M}$ website views per year

At $\mathrm{BMC}$, research is always in progress.

Learn more biomedcentral.com/submissions 